Review

\title{
Occurrence and Control of Legionella in Recycled Water Systems
}

Patrick K. Jjemba ${ }^{1, *}$, William Johnson ${ }^{1}$, Zia Bukhari ${ }^{2}$ and Mark W. LeChevallier ${ }^{2}$

1 American Water Research Laboratory, 213 Carriage Lane, Delran, NJ 08075, USA;

E-Mail: william.johnson2@amwater.com

2 American Water, 1025 Laurel Oak Road, Voorhees, NJ 08043, USA;

E-Mails: zia.bukhari@amwater.com (Z.B.); mark.lechevallier@amwater.com (M.W.L.)

* Author to whom correspondence should be addressed; E-Mail: Patrick.jjemba@amwater.com; Tel.: +1-856-764-4919.

Academic Editor: Lawrence S. Young

Received: 23 May 2015 / Accepted: 24 June 2015 / Published: 1 July 2015

\begin{abstract}
Legionella pneumophila is on the United States Environmental Protection Agency (USEPA) Candidate Contaminant list (CCL) as an important pathogen. It is commonly encountered in recycled water and is typically associated with amoeba, notably Naegleria fowleri (also on the CCL) and Acanthamoeba sp. No legionellosis outbreak has been linked to recycled water and it is important for the industry to proactively keep things that way. A review was conducted examine the occurrence of Legionella and its protozoa symbionts in recycled water with the aim of developing a risk management strategy. The review considered the intricate ecological relationships between Legionella and protozoa, methods for detecting both symbionts, and the efficacy of various disinfectants.
\end{abstract}

Keywords: amoeba; disinfection; Legionella; protozoa

\section{Introduction}

Recycled water is water, which, as a result of treatment of waste, is suitable for direct beneficial purposes. Water recycling is a very ancient practice. However, the practice has intensified amid tremendous advances in water treatment technologies, an increased interest in resource conservation, enhanced water demand stress, drought episodes and the associated debate about climate change. Legionella pneumophila has a high epidemiological significance and is currently on the candidate 
contaminant list 3 (CCL3; [1]). It was one of 20 priority organisms of concern in recycled water quality identified recently [2]. Several other research groups have also recognized the importance of Legionella sp. in recycled water [3-5]. Although no legionellosis outbreak has been directly associated with recycled water, outbreaks related to water intrusion [6,7], cooling towers [8], a mist humidifier [9], and distribution systems [10] have been reported. Thus, it is in the recycled water industry's best interest to proactively prevent future outbreaks as Legionella spp. are very prevalent in the product. Overall, Legionella infections occur sporadically and in outbreaks but in most instances, the source of infection is not always easily deciphered. Currently, legionellosis is the most common waterborne disease reported in the US and surveillance data show a steady increase of cases [11,12]. Members of the genus are Gram-negative bacteria, which occur ubiquitously in aquatic and engineered systems. To date, 52 species and 70 serotypes have been identified [13,14]. Although fairly ubiquitous, Legionella spp. thrive in warm $\left(25-42{ }^{\circ} \mathrm{C}\right)$ water, particularly in areas where water stagnates [15]. They occur as planktonic cells, biofilm denizens, or as intracellular symbionts in protozoa, especially free-living amoeba.

Models to understand the risk from Legionella sp. in potable water systems have been developed. There are apparent differences between recycled and potable water. Most distinct is the relatively higher level of nutrients in recycled compared to potable water. Despite differences, modeling processes from potable systems can be a useful basis for comparative analysis in managing risk from Legionella sp. in recycled water systems. Occurrence of Legionella sp. in potable water plumbing systems has been documented by numerous research groups (Table 1). Evidence from potable water systems showed most abundance of Legionella spp in heated units, such as cooling towers, hot tubs, and hot water tanks. Some of the key considerations in potable water systems that warrant inclusion in a risk assessment and management strategy are the importance of temperature and protozoa host symbionts. For example, L. pneumophila increased by three log units in cooling tower foam compared to the bulk water column [16]. Foaming is a common occurrence in wastewater treatment especially where organic acids and other antiscalants are used. Colburne et al. [16] recommended treatment processes which minimize foaming, during wastewater treatment processes for generating recycled water. Dead end points, with long retention time and areas in the distribution system receiving water flow from more than one direction were more prone to colonization by Legionella spp. [17].

Some amoeba species internalize bacteria. Data from Table 1 also strongly indicate the need to consider protozoa in addressing the impact and risks associated with Legionella sp. in water systems. Although conducted in potable water systems, Figure 1 shows the intricate association of amoeba with Legionella sp. throughout the treatment process and subsequent distribution. Both amoeba and Legionella in those instances were detected using conventional culture methods and polymerase chain reaction (PCR), but the latter were rarely detected by conventional culture methods [18]. The results also show the replication of Legionella spp. in granular activated carbon (GAC) filters and survival after disinfection, continuing to grow in distribution systems.

Protozoa were also consistently detected in other Legionella-infested assemblies. For example, protozoa were detected in $29 \%(n=231)$ of hot water recirculation systems. A majority $(93 \%)$ of the protozoa detected were amoeba [19]. Flagellates and ciliates were detected in only $26.8 \%$ and $3.6 \%$, respectively. Similarly, Acanthamoeba sp. and Vermamoeba vermiformis were detected in two potable water distribution systems using molecular probes [20]. Yamamoto et al. [21] detected ciliates and flagellates in cooling towers. 


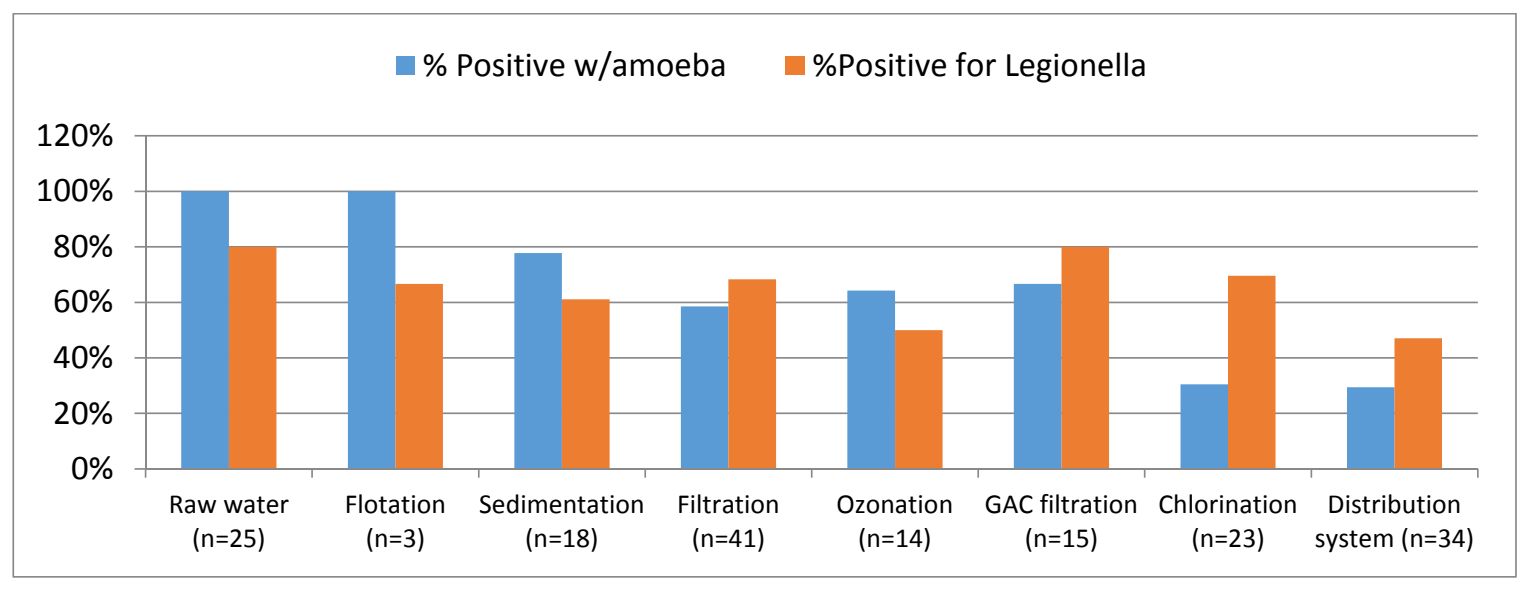

Figure 1. Positive samples for amoeba and Legionella spp. in ten treatment systems (Figure compiled from Loret and Greub [18]).

Table 1. Selected examples of Legionella spp. occurrence in potable water distribution and plumbing systems.

\begin{tabular}{|c|c|c|c|c|}
\hline Location & Organism & $\%$ Occurrence & $\begin{array}{l}\text { Mean Density in } \\
\text { Positive Samples }\end{array}$ & Refs. \\
\hline \multirow{4}{*}{$\begin{array}{c}\text { Blacksburg-Christiansburg-VPI } \\
\text { Water Authority } \\
\text { (Virginia, USA; } n=29 \text { ) }\end{array}$} & Legionella spp. & 69 & $187 \mathrm{gc} / \mathrm{mL}$ & \multirow{4}{*}[20]{} \\
\hline & L. pneumophila & 13.7 & $9.8 \mathrm{gc} / \mathrm{mL}$ & \\
\hline & Vermamoeba vermiformis & 27.6 & $1.2 \times 10^{4} \mathrm{gc} / \mathrm{mL}$ & \\
\hline & Acanthamoeba sp. & 13.7 & $2.2 \mathrm{gc} / \mathrm{mL}$ & \\
\hline \multirow{4}{*}{ Pinellas County, FL (USA; $n=15$ ) } & Legionella spp. & 100 & $100.8 \mathrm{gc} / \mathrm{mL}$ & \multirow{4}{*}{ [20] } \\
\hline & L. pneumophila & 20 & $90.4 \mathrm{gc} / \mathrm{mL}$ & \\
\hline & Vermamoeba vermiformis & 73.3 & $781.7 \mathrm{gc} / \mathrm{mL}$ & \\
\hline & Acanthamoeba sp. & 6.7 & $\mathrm{ND} *$ & \\
\hline Catalonia (Spain) & Legionella spp. & 35 & $6.9 \mathrm{CFU} / 100 \mathrm{~mL}$ & {$[19]$} \\
\hline \multirow{4}{*}{ Nara/Gifu/Aichi/Shizuoka (Japan) } & Legionella sp. & & $1.6 \mathrm{CFU} / 100 \mathrm{~mL}$ & \multirow{4}{*}[21]{} \\
\hline & Amoeba & & $2.4 \mathrm{MPN} / 100 \mathrm{~mL}$ & \\
\hline & Ciliates & & 1.1 MPN/100 mL & \\
\hline & Flagellates & & $2.8 \mathrm{MPN} / 100 \mathrm{~mL}$ & \\
\hline Pittsburg Psychiatric Hospital & Legionella sp. & $50 \%-90 \%$ & $117.5 / \mathrm{swab}$ & {$[22]$} \\
\hline London (cooling tower foam) & L. pneumophila 1 & & $10^{5} \mathrm{cfu} / \mathrm{mL}$ & {$[16]$} \\
\hline Miyazaki, Japan (spa) & Legionella sp. & & $1.5 \times 10^{7} \mathrm{cfu} / \mathrm{L}$ & \multirow{3}{*}[23]{} \\
\hline $\begin{array}{c}\text { Shizuoka, Japan } \\
\text { (outdoor thermal spring) }\end{array}$ & Legionella sp. & & $5.7 \times 10^{5} \mathrm{cfu} / \mathrm{L}$ & \\
\hline $\begin{array}{c}\text { Shizuoka, Japan } \\
\text { (indoor thermal spring) }\end{array}$ & Legionella sp. & & $8.8 \times 10^{5} \mathrm{cfu} / \mathrm{L}$ & \\
\hline Singapore & Legionella sp. & $\begin{array}{c}15.6 \% \text { (cooling towers) } \\
12.4 \% \text { (fountains) }\end{array}$ & No reported & {$[14]$} \\
\hline Israel & Legionella spp. & $7.2-18.2$ over 5 years & Not reported & {$[13]$} \\
\hline
\end{tabular}

$* \mathrm{ND}=$ Not detected (but some gene copies detected in the biofilm).

The risk and infectivity of Legionella can differ depending on the source water, treatment processes, and intended use of the recycled water. A recent survey of 10 recycled water systems highlighted typical 
uses in the United States (Table 2). Also included in the table is the potential for each use to generate aerosols. Legionella is a nonconventional waterborne pathogen, as it is not transmitted orally. Transmission is through mechanical means, which generate aerosols including sprinklers, cooling towers (air-conditioning) and shower heads; mechanisms which prominently feature in the use of recycled water. Once inhaled in aerosols, the bacteria are internalized in the lungs by alveolar macrophages and epithelial cells, replicate within the phagosomes and eventually lyse the host macrophages. This process is similar but not identical to the organism being parasitized by protozoa [24]. The ecological relationship between Legionella and protozoa is reviewed underneath.

Table 2. Typical uses of recycled water for 10 systems in the US and related potential to generate aerosols.

\begin{tabular}{lcc}
\hline \multicolumn{1}{c}{ Use } & System (\%) & $\begin{array}{c}\text { Potential for Generating } \\
\text { Aerosols }\end{array}$ \\
\hline Irrigation (parks, medians, farms, lawns, etc.) & 90 & Low (drip) to high (aerial spray) \\
Cooling towers/Boilers & 50 & High \\
Construction & 20 & Moderate \\
Dust control & 10 & Moderate \\
Washing (cars, windows) & 10 & Moderate \\
Street sweeping & 10 & Moderate \\
Fire fighting & 10 & Moderate \\
Toilet/Urinal flushing & 30 & Low \\
Groundwater recharge & 20 & Low \\
Animal watering & 10 & Low \\
Wetlands & 10 & Low \\
\hline Total is more than $100 \%$ as most systems utilized recycled water for multiple uses. Source: Table \\
compiled from [25].
\end{tabular}

\section{Ecology of Legionella sp. and Its Protozoa Host}

Ecology is the study of the distribution, activities and interactions of organisms with their habitats. Such studies normally entail the isolation, identification and measurement of the activities of the organisms, assessment of their interactions with other organisms, and determining their response to abiotic environments [26]. A typical recycled water distribution system is inherently prone to intermittent flow changes as a result of changes in water pressure and demand [27]. It also tends to have low disinfectant residual and relatively high levels of nutrients (e.g., organic carbon, nitrogen and phosphorus), which in turn support growth and survival of microorganism including Legionella sp. [25,28]. These characteristics create an environment with many dead ends and even more dissipation of the disinfectant residual, an important preservative.

Legionella sp. can multiply in biofilms and/or as an intracellular symbiont with protozoa in the distribution system [18]. Biofilms are assemblages of bacteria encased in extracellular polymeric compounds, attached to phase boundaries or surfaces. Such an adherent and hydrated environment protects bacteria from desiccation and harmful chemicals [29].

Colonization of biofilms by Legionella spp. occurred within a short timeframe attaching to the substratum using pili and flagella [30]. Expression of the flaA gene (involved in L. pneumophila 
flagellum assembly and movement to the biofilm) also increased by $40 \%$ under a biofilm environment. However, L. pneumophila did not show an absolute requirement for pili and secretions implicated in the attachment and retention in biofilms [24]. Colonization and retention of pili deficient mutants was sustained in the presence of amoeba. Legionella pneumophila also expressed competence and adherence-associated pili (CAP) on its surface, which enhanced its ability to adhere to surfaces and biofilms [31]. Under intercellular and biofilm environments, Legionella sp. can be protected from disinfectants [32,33], with important ecological ramifications highlighted later in the review.

Coordination between Legionella sp. and biofilm colonization was displayed by a dramatic decrease of biofilm-associated Legionella sp. in a rotating annular reactor (RAR) in the absence of amoeba (Figure 2). By contrast, addition of Acanthamoeba castellani reversed the trend and increased the density of Legionella by $2.9 \mathrm{log}$ units in the biofilm. Amoebae were lysed within $72 \mathrm{~h}$, releasing more Legionella sp. into the bulk water. Those results collectively demonstrated enhanced survival of Legionella sp. in the presence of the amoeba host. From a practical perspective, control of Legionella sp. in recycled water may not be feasible unless it is combined with controlling amoebae as well.

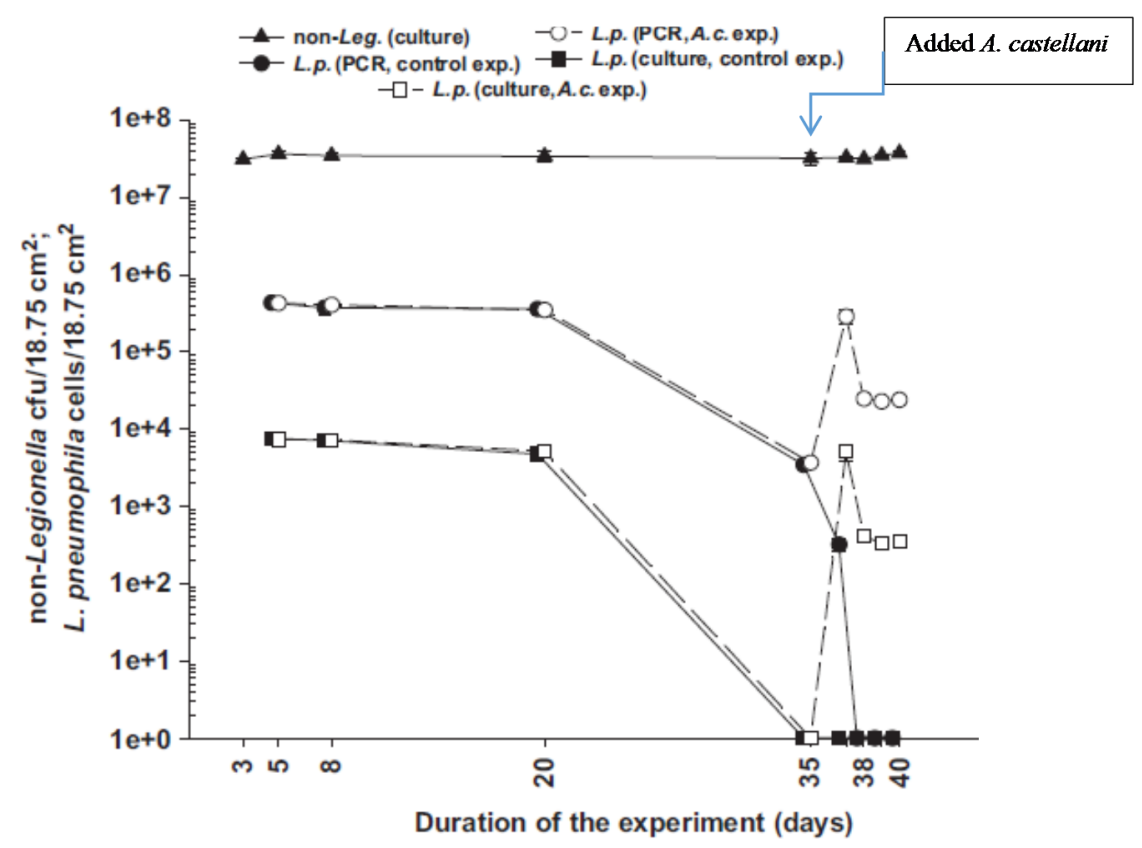

Figure 2. Evolution of biofilm-associated Legionella and a mixture of other (non-Legionella) bacterial species. Acanthamoeba castellani (A.c.) were added in the reactor on day 35 . Non-Legionella bacteria in the reactor included Aeromonas hydrophila, Escherichia coli, Flavobacterium breve and Pseudomonas aeruginosa. (Source: [30]).

Amoeba exist in a vegetative form (trophozoites) or in a resting form (cysts), the latter enabling survival under adverse environmental conditions including low nutrients and higher temperatures. After ingestion of bacteria, amoebae formed small vesicles of $<5 \mu \mathrm{m}$ which harbor Legionella and other symbionts such as Mycobacterium, Enterobacterium and Vibrio spp [34]. Each vesicle contained an estimated 20 to 200 bacteria. Feeding experiments significantly increased the number of vesicles formed by $A$. castellani and $A$. polyphaga when the amoeba were fed on a mixture of E. coli and Legionella sp. compared to amoeba solely fed on either bacterial species alone [34]. There was no evidence of 
preferential feeding of the amoeba on either type of bacteria in the mixture. Concrete enumeration of each bacterial type in the tightly packed vesicles was not feasible.

Some Legionella species, notably L. drancourtii and L. jeonii, are obligate intracellular denizens of protozoa, unable to grow axenically in free media without protozoa [35]. The internalized bacteria are able to grow within vesicles) and even survive in amoeba cysts. These internalization and release processes may contribute to survival in a viable but non-culturable (VBNC) state [36]. When environmental conditions become suitable for encystation, Legionella sp. egress and re-infect new amoebae. Through this behavior, free-living amoeba share many common features with mammalian phagocyts such as macrophages, enhancing Legionella's ability to resist phagocytosis [37,38]. Thus, amoeba may act as Trojan horses, providing a training ground for Legionella sp. to enhance its infectivity and pathogenicity to humans with important ecological and epidemiological implications.

Thomas et al. [39] analyzed free-living amoeba at each step of a water treatment system and recovered bacteria-infected amoeba mainly from filter media. They attributed the increased presence of infected amoeba in this environment to biofilms, which favored contact between the free living amoeba and bacteria. Higher densities of bacteria-infected amoeba in biofilms compared to the surrounding water in cooling towers were also documented by Berk et al. [40]. Biofilms are initiated by attachment and adherence of organisms to one another and/or to abiotic surfaces. Composition of the surface material plays a major role in determining the extent of adherence. For example, L. pneumophila attached quite well to plastic and other materials commonly used in recycled water piping, reservoirs and appurtenances [34]. Attachment, colonization and subsequent formation of the biofilm was also enhanced by carbon, especially at relatively low temperatures (i.e., $20{ }^{\circ} \mathrm{C}$; [41]).

Legionella pneumophila biofilms were significantly influenced by temperature and emerged within three days at $37{ }^{\circ} \mathrm{C}$ and $42{ }^{\circ} \mathrm{C}$ compared to 11 days at $25^{\circ} \mathrm{C}$ [29]. The biofilms formed at $25^{\circ} \mathrm{C}$ were more adherent, thinner and rod-shaped but non-filamentous whereas those formed at $37{ }^{\circ} \mathrm{C}$ and $42{ }^{\circ} \mathrm{C}$ were filamentous (Figure 3). The filamentous biofilms were possibly a fitness trait against adverse environments [33]. These findings can have significant ecological implications for public health where the recycled water is subjected to elevated temperatures typical of water heaters and cooling towers. At elevated temperatures the formed biofilms will be less stable and more prone to slough off releasing Legionella spp. (and possibly associated protozoa) into the bulk water. The released organisms ultimately end up in aerosols. Because of the importance of temperature extremes on Legionella sp. and amoeba ecology, their occurrence in cooling towers and water heaters is briefly reviewed underneath.

\subsection{Cooling Towers}

Cooling towers operate through evaporation of water into the atmosphere. The use of recycled water for cooling towers in the United States and other countries is increasing. Yamamoto et al. [21] surveyed 40 cooling towers in Japan where water temperatures ranged between $8.3{ }^{\circ} \mathrm{C}$ to $35{ }^{\circ} \mathrm{C}$ and detected Legionella sp. in $73 \%$ of the towers. Of the 359 isolates identified, $90 \%$ were L. pneumophila, with serogroup 1 as the most prevalent. Other serogroups included 3 (18 strains), 4 (2 strains), 5 (8 strains), 6 (26 strains) and unidentified serogroups (65 strains). Maximum Legionella densities were detected in water of $\mathrm{pH} 8.4$ to 9.1 and temperature $26.3{ }^{\circ} \mathrm{C}$ to $29.9^{\circ} \mathrm{C}$ [21]. No water of acidic $\mathrm{pH}$ was encountered in the towers. Predominantly alkaline conditions in cooling were also reported by Miller and 
Simpson [42]. The density of Legionella $\mathrm{sp}$. in the towers correlated positively with temperature, water $\mathrm{pH}$, and amoeba abundance; but not with heterotrophic bacteria (Table 3). A similar conclusion about HPCs was reached by Serrano-Suárez et al. [19]. The highest Legionella densities of $10^{5} \mathrm{CFU}$ Legionella sp./100 mL in the towers registered by Yamamoto et al. [21] were in summer but Legionella sp. were also consistently present in the towers at $10^{2}$ to $10^{3} \mathrm{CFU} / \mathrm{mL}$ in winter. Protozoa (i.e., amoeba, ciliates and flagellates) of several taxa were detected in $98 \%$ of the samples throughout the year at densities of 10 to $10^{3} \mathrm{MPN} / 100 \mathrm{~mL}$. The towers contained biofilms and deposits, which, together with the protozoa, may have protected Legionella sp.

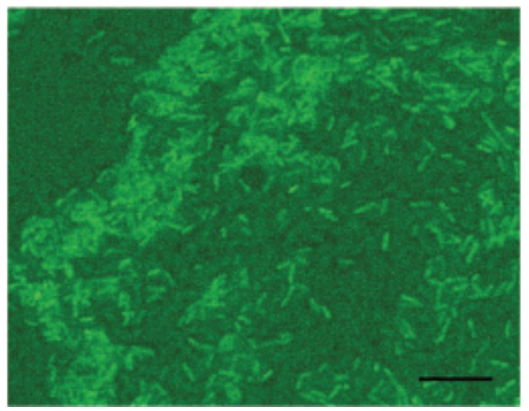

(A)

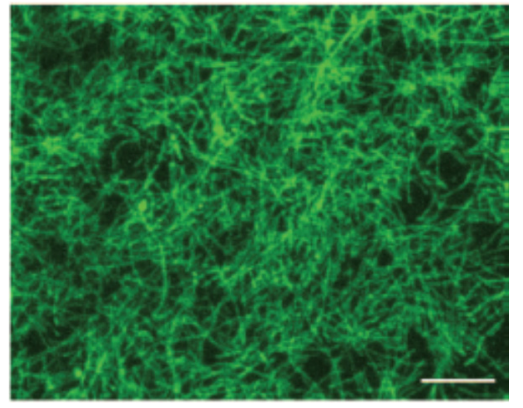

(B)

Figure 3. Structure of Legionella pneumophila biofilm grown at (A) $25{ }^{\circ} \mathrm{C}$ for 18 days [non-filamentous growth] and (B) $37{ }^{\circ} \mathrm{C}$ for 6 days (filamentous growth). Bars are $10 \mu \mathrm{m}$. Figure adapted from [29] with permission from American Society for Microbiology.

Table 3. Correlation of various parameters in 40 cooling towers in Japan.

\begin{tabular}{ccccc}
\hline Parameter & Water Temperature & $\mathbf{p H}$ & Heterotrophic Bacteria & Legionella \\
\hline Heterotrophic bacteria & 0.190 & $0.331 *$ & & \\
Legionella & $0.311^{*}$ & $0.319^{*}$ & 0.104 & \\
Ciliates & $0.332^{*}$ & $0.388^{*}$ & 0.146 & $0.300 *$ \\
Flagellates & 0.122 & 0.042 & -0.079 & $0.383 *$ \\
Amoeba & $0.328^{*}$ & 0.208 & 0.002 & $0.300 *$ \\
\hline
\end{tabular}

* Correlation was significant $(p<0.01 ; 99 \%$ confidence; Source: [21].

More recently Mouchtouri et al. [43] detected Legionella sp. in 49\% of 96 cooling towers surveyed in Greece. One third of the samples tested had $\geq 40 \mathrm{cfu} / \mathrm{L}$ and of the 69 isolates, $80 \%$ were L. pneumophila, with $75 \%$ as L. pneumophila serotype 1 . A positive correlation was found in towers with $<0.5 \mathrm{mg}$ residual chlorine/L. Legionella spp. were also detected in several cooling towers in Florida [17] and in 47\% of the cooling towers sampled in Singapore [14]. Legionella sp. occurrence in recycled water-cooling towers has not been deliberately studied but countries such as Singapore have heavy usage of recycled water.

\subsection{Water Heaters}

Although recycled water is not yet widely used for domestic purposes, it is used at some commercial facilities for boiler makeup water and other industrial processes where heating is routinely conducted. Parallels can be drawn from experiences with occurrence of Legionella spp. and protozoa in domestic 
hot water systems. Serrano-Suárez et al. [19] reported most of the Legionella isolates in hot water circulation systems between $25{ }^{\circ} \mathrm{C}$ and $45{ }^{\circ} \mathrm{C}$ but some isolates were obtained from locations outside this temperature range. A few Legionella spp. survived at $70{ }^{\circ} \mathrm{C}$ [32]. Protozoa host proliferation and survival at high temperatures for thermophiles such as Vermamoeba vermiformis, has been documented although prevalence of amoeba was significantly lowered above $60{ }^{\circ} \mathrm{C}[44,45]$. Acanthamoeba polyphaga cysts were resistant to $62^{\circ} \mathrm{C}$ and although reduced by $5 \operatorname{logs}$ after a $2 \mathrm{~h}$ contact of $62-65^{\circ} \mathrm{C}$, viable cysts were not totally eliminated until heating at $70{ }^{\circ} \mathrm{C}$ for at least $30 \mathrm{~min}$ [18]. Similarly Vermamoeba vermiformis cysts persisted until contact to $60{ }^{\circ} \mathrm{C}$ for $30 \mathrm{~min}$. These observations have ramifications for persistence of free-living amoeba and symbiotic Legionella sp. in water heaters and boilers. Berk et al. [34] reported lysis of amoeba at $35^{\circ} \mathrm{C}$, releasing the bacteria loaded vesicles. The released bacteria were still viable.

\section{Challenges in Detecting Legionella spp. and Their Protozoa Hosts}

Legionella spp. were initially recovered using guinea pigs and embryonated hen eggs [46]. However, that process was very expensive and time consuming. Five modern laboratory methods for detecting Legionella spp. in recycled water and about an equal number of methods for detecting Acanthamoeba sp. and Naegleria sp. (two more of the 20 priority organism of importance in recycled water previously highlighted (Table 4) were used by different laboratories. Most of them involved isolation of the respective organism using a formulated media. However, most of them had not been validated through a round robin testing process [2]. The validation process utilizes statistically sound testing, to identify sensitive, specific, and reproducible methods that help to improve the reliability of monitoring programs [47]. Validation also establishes the operational limits and laboratory performance specifications relevant to the intended use of the method. If conducted properly, validation should address sampling and sample preservation issues; include analytical blanks, reference standard samples, spikes and recoveries from such spikes, duplicate sample, and calibration checks; establish method detection limits and method performance range; include positive and negative controls and sterility checks; assess viability and infectivity status of the organism; establish sources of interferences that can affect data reliability; examine variable matrix applicability (e.g., varying $\mathrm{pH}$, conductivity, and organic carbon levels); and exert consistent total quality management as to ensure high specificity, sensitivity, precision, and accuracy.

Data based on these less than perfect methods reveal that the density of Legionella sp. may greatly vary in response to the density and composition of protozoa and biofilms in the system. Where Legionella spp. get embedded in protozoa, they remain protected and adapt a wide range of forms including the viable but non-culturable. For example, Legionella spp. were detected by PCR in $41 \%$ of 231 samples from hot water recirculation systems but a culture-based method detected the organism in only $27 \%$ of the samples [19]. Logistic analysis associated Legionella sp. with at least $0.095 \mathrm{mg} \mathrm{Fe} / \mathrm{L}$. Iron is essential for the growth of Legionella sp. whereas copper is inhibitory. Both metals can be derived from pipes and appurtenances, depending on composition of the distribution system infrastructure. 
Table 4. Summary of Methods for Detecting Legionella and Two Important Amoebae in Reclaimed Water.

\begin{tabular}{|c|c|c|c|c|c|}
\hline Organism & Detection Method ${ }^{\text {a }}$ & $\begin{array}{l}\text { Aggregate } \\
\text { Score }\end{array}$ & $\begin{array}{l}\text { Round-Robin } \\
\text { Tested? }\end{array}$ & Growth Media & Key Refs. \\
\hline \multirow{4}{*}{ Acanthamoeba } & Membrane filtration and incubation & 29 & No & $\begin{array}{c}\text { Non-nutrient agar and peptone yeast } \\
\text { extract glucose (PYG) }\end{array}$ & [48] \\
\hline & $\begin{array}{c}\text { Membrane filtration, enrichment on } \\
\text { Neff's media and PCR }\end{array}$ & 31 & No & $\begin{array}{l}\text { Neff's saline non nutrient agar and } \\
\text { peptone yeast extract glucose (PYG) }\end{array}$ & [49-51] \\
\hline & Centrifugation and incubation & 29 & Yes & Non-nutrient agar & {$[52,53]$} \\
\hline & $\begin{array}{c}\text { Membrane filtration, plaque } \\
\text { formation and PCR }\end{array}$ & 30 & No & Non-nutrient agar & {$[54]$} \\
\hline \multirow{9}{*}{ Naegleria } & $\begin{array}{l}\text { Membrane filtration (or centrifugation) } \\
\text { and incubation }\end{array}$ & 31 & No & $\begin{array}{c}\text { Non-nutrient agar and peptone yeast } \\
\text { extract glucose (PYG) }\end{array}$ & [55] \\
\hline & $\begin{array}{l}\text { Membrane filtration, } \\
\text { enrichment, and PCR }\end{array}$ & 34 & No & $\begin{array}{l}\text { Neff's saline non-nutrient } \\
\text { agar with } E \text {. coli lawn }\end{array}$ & {$[55]$} \\
\hline & $\begin{array}{c}\text { Membrane filtration, } \\
\text { plaque formation, and PCR }\end{array}$ & 32 & No & Non-nutrient agar & {$[54]$} \\
\hline & $\begin{array}{c}\text { Enzyme-linked } \\
\text { immunosorbent assay (ELISA) }\end{array}$ & 38 & No & Non-nutrient agar & {$[56]$} \\
\hline & Isoenzyme electrophoretic focusing (IEF) & 32 & No & Non-nutrient agar & {$[56,57]$} \\
\hline & $\begin{array}{c}\text { Restriction fragment length } \\
\text { polymorphism (RFLP) }\end{array}$ & 32 & No & Non-nutrient agar & {$[56,58]$} \\
\hline & $\begin{array}{l}\text { Concentration by } \\
\text { centrifugation and culture }\end{array}$ & 39 & No & Non-nutrient agar & {$[59,60]$} \\
\hline & Real-time PCR & 40 & No & Not applicable & [61-63] \\
\hline & $\begin{array}{c}\text { Concentration by centrifugation and } \\
\text { then nested PCR }\end{array}$ & 30 & No & Nutrient agar & {$[64,65]$} \\
\hline \multirow{5}{*}{ Legionella } & $\begin{array}{l}\text { MF, heating, acidification } \\
\text { and plating on CYE }\end{array}$ & 37 & No & CYE agar & {$[66]$} \\
\hline & $\begin{array}{c}\text { MF, acidification and } \\
\text { plating on BCYE }\end{array}$ & 37 & No & BCYE agar & {$[28,67]$} \\
\hline & Direct fluorescent-antibody (DFA) staining & 36 & No & Not applicable & [67] \\
\hline & PCR with EnviroAmp kit & 47 & No & Not applicable & {$[67,68]$} \\
\hline & Semi-nested PCR & 41 & No & Not applicable & [69] \\
\hline
\end{tabular}

${ }^{a}$ Detection method in bold were most comprehensive based on an aggregate scoring exercise (see details in [2]).

In all instances of the methods listed in Table 4, the use of PCR to detect either Legionella sp. or its protozoa host was more sensitive than conventional culture methods. Similar observations were made by Mario et al. [70] and Merault et al. [71]. PCR-based methods also had a much shorter turnaround time (i.e., hours instead of days to weeks). However, it has been urged that presence of nucleic acids and the resultant amplification by PCR in itself has no reflection on whether the detected nucleic acid material is from live or dead cells or how infective the cells are. To detect viable cells using PCR-based methods, modifications incorporated propidium monoazide (PMA) or ethidium monoazide (EMA) dyes with bacteria [72,73] and protozoa [74]. Both dyes preferentially penetrate dead or damaged cells, but not viable cells with intact cell membranes. Once inside the cell, the dye molecules intercalate 
with DNA and covalently bind upon exposure to light. The photoactive moiety forms a stable DNA-PMA or DNA-EMA complex that interferes with PCR amplification. Thus, when applied, only DNA from viable cells (e.g., those with intact membranes) is amplified during PCR, enabling differentiation between viable and nonviable cells. However, the process can succumb to interference from the matrix. For example, Gedalanga and Olson [75] used this technique on raw sewage and chlorine-disinfected recycled water effluents and found no distinction between amplification of live and dead cells. Similarly, higher levels of suspended solids, turbidity and inhibitory substances interfered with PCR or PMA-qPCR in water [76,77]. Interference to EMA-qPCR and PMA-qPCR may also be due to the presence of viable but nonculturable cells.

Contrary to PCR being widely reported as more sensitive than culturing, Pryor et al. [17] reported more consistent detection of Legionella spp. by culture methods compared to PCR; with more Legionella sp. isolated at $30{ }^{\circ} \mathrm{C}$ than the typical $35{ }^{\circ} \mathrm{C}$ incubation temperature. Semi-nested PCR was conducted with LEG 225 and LEG 858 primers enclosing 654 bp in the first step and with LEG 448 and LEG 858 in the second step. However, PCR was conducted on DNA from single presumed Legionella colonies but there is no indication as to how the colonies, which were PCR negative had been confirmed to be Legionella sp. in culture in the first place. Although acid treatment of samples prior to plating on BCYE had been conducted, this process only reduces but does not completely guard against growth of other organisms on the media.

\subsection{Control of Legionella spp. and Protozoa in Recycled Water}

A number of measures involving physical, thermal and chemical means are used to control Legionella sp. and protozoa in recycled water. Physical methods include use of filtration whereas thermal methods rely on freezing, heating and pasteurization techniques. Berk et al. [34] subjected samples to three cycles of freeze-thawing $\left(-70{ }^{\circ} \mathrm{C}\right.$ and $\left.+35^{\circ} \mathrm{C}\right)$ followed by sonication to destroy amoeba trophozoites. The treatment left the structural integrity of their vesicles and embedded Legionella intact.

Most widely used by the industry to control Legionella $\mathrm{sp}$. and protozoa are chemical disinfectants, particularly oxidizing agents such as chlorine, chlorine dioxide, chloramine, and ozone. Other oxidizing agents include iodine, hydrogen peroxide, potassium permanganate and bromine but these are rarely used and will not be discussed further. Because of its importance to the industry, photochemical disinfection using UV is also reviewed. The disinfectant should ideally be able to inactivate microorganisms in bulk water, control or remove biofilm and inactivate microorganisms associated with that biofilm. Overall, the efficacy of disinfectants depends on the culture condition of Legionella spp. and their host protozoa. For example, Cargill et al. [78] reported more susceptibility to chlorine and iodine to Legionella sp. grown on agar media than broth culture. Similarly, unattached (i.e., plankatonic) Legionella sp. were hundredfold more susceptible to iodine than biofilm-based organisms which required more disinfectant to penetrate the biofilm. It is also more difficult to kill Legionella associated with protozoa and even more difficult when the bacteria are associated with cysts $[79,80]$. Specific disinfectants can also be impacted by chemical parameters such as organic matter content, $\mathrm{pH}$ and temperature as discussed for each disinfectant underneath. All of these considerations are important when designing a management strategy. 
In a recent survey of 71 recycled water plants in the US and Australia, chlorine was the dominant disinfectant, although a few utilities combined it with UV or ozone (Figure 4). Seven percent of the utilities used only UV disinfection, but more than three times as many utilities combined UV with another disinfectant, such as sodium hypochlorite, to provide a residual. A few (13\%) other utilities did not disinfect or disclose information about disinfection practices. Choice of the disinfectant depended on cost, efficacy, ease of handling and preference. Disinfectant efficacy is often standardized based on the concept of a CT value (i.e., concentration $\times$ time of exposure) necessary for a $2-\log \left(\mathrm{CT}_{99 \%}\right)$ or 3-log (CT99.9\%) inactivation. Because Legionella sp. can use protozoa as a protective shield against disinfectants, it is imperative to consider the efficacy of each disinfectant to both organisms. Efficacy of specific disinfectants on Legionella sp. and host protozoa is reviewed underneath.

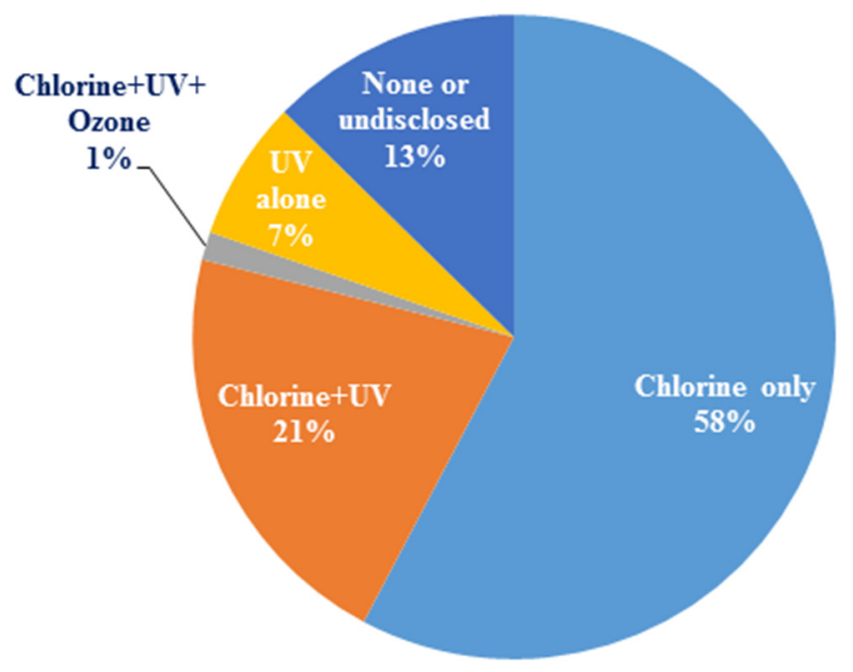

Figure 4. Disinfectants used by the recycled water industry (Note: Chlorine refers to all chlorine-based disinfectants as no distinction was made during the survey; Source: [25]).

\subsection{Chlorine}

Chlorine adversely affects the respiratory, transport activities and nucleic acids of microorganisms, leading to their inactivation [32]. Unlike potable water where trihalomethane concentrations of $80 \mu \mathrm{g} / \mathrm{L}$ or less are recommended by the USEPA, high chlorine residuals would be preferred to the point of use for some non-potable recycled water purposes. A main exception to this generalization is where the recycled water is intended for direct potable reuse. Mouchtouri et al. [43] disinfected Legionella-positive cooling towers by circulating water with $5 \mathrm{mg}$ free chlorine/L for $5 \mathrm{~h}$ (i.e., $\mathrm{CT}=25$ $\mathrm{mg} \mathrm{min} / \mathrm{L}$ ). Systems with $\mathrm{pH}>8.0$ received higher free chlorine dosages of 15 to $20 \mathrm{mg} / \mathrm{L}$ to achieve the required disinfection level. Disinfection was considered successful when samples showed $<1 \mathrm{CFU} / \mathrm{mL}$. Planktonic Legionella spp. resuspended in water were completely eliminated within $3 \mathrm{~min}$ by $2 \mathrm{mg} \cdot \mathrm{L}^{-1}$ free chlorine derived from sodium hypochlorite [81]. By comparison, Legionella spp. in protozoa cysts survived 25-fold more chlorine disinfectant after $18 \mathrm{~h}$ [82].

Hyperchlorination with 4 to $6 \mathrm{mg} / \mathrm{L}$ decreased L. pneumophila in plumbing systems by 5 to $6 \operatorname{logs}$ over $6 \mathrm{~h}$ [83]. The decline in Legionella sp. was more rapid at $43{ }^{\circ} \mathrm{C}$ than at $25^{\circ} \mathrm{C}$. However, a higher dose of chlorine was required at the higher temperature to overcome thermal decomposition and maintain a chlorine residual of 4 to $6 \mathrm{mg} / \mathrm{L}$. The higher chlorine applications had to be applied in multiple doses as 
similarly high single applications were not effective over time (Figure 5). Chlorine was more effective with increasing temperatures implying that the warmer the water, the more efficacious is chlorine as a disinfectant. Enhanced efficacy of chlorine at higher temperatures is possibly due to accelerated binding of the chemical to the cell surface. This has practical applications, as it is easier to meet CT requirements in summer than in winter.

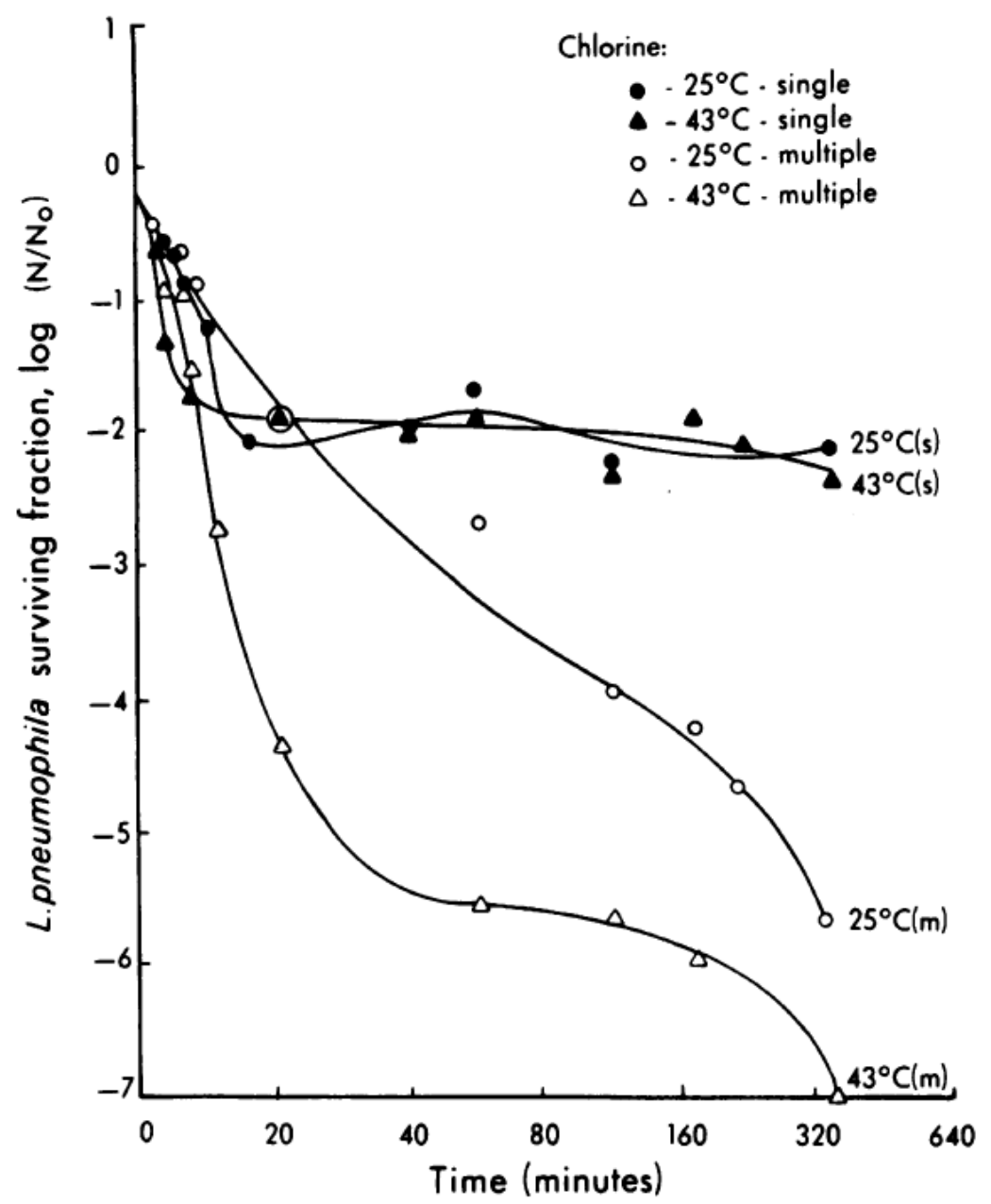

Figure 5. Efficacy of chlorine on Legionella pneumophila in a model system at ambient and high temperatures. To maintain a residual of 4 to $6 \mathrm{mg} / \mathrm{L}$ (attained with $18 \mathrm{~mL}$ at $25{ }^{\circ} \mathrm{C}$ and $40 \mathrm{~mL}$ at $43{ }^{\circ} \mathrm{C}$ ), treatment with $\mathrm{m}$ received multiple application of chlorine whereas those with an s received a single dose of chlorine. (Source: [83] with permission from American Society for Microbiology).

De Jonckheere and van de Voorde [84] documented more sensitivity to chlorine by Naegleria cysts (CT $99 \%$ of 9 to $30 \mathrm{mg} \mathrm{min} / \mathrm{L}$; $\mathrm{pH} 7.35$ and $25^{\circ} \mathrm{C}$ ) as compared to Acanthamoeba cysts (CT $99 \%$ of 1260 to $6480 \mathrm{mg} \mathrm{min} / \mathrm{L} ; \mathrm{pH} 7.35$ and $25^{\circ} \mathrm{C}$; Table 5). Acanthamoeba polyphaga cysts required high levels of free chlorine (i.e., $75 \mathrm{mg} / \mathrm{L}$ for a contact time of $18 \mathrm{~h}$ at $25^{\circ} \mathrm{C}$; a high CT of $81,000 \mathrm{mg} \mathrm{min} / \mathrm{L}$ ) to control excystation [82]. The pathogenic Naegleria fowleri were generally more susceptible to chlorine disinfection compared to non-pathogenic N. gruberi. However, some Acanthamoeba spp., another pathogenic organism and are fairly prevalent in recycled water, required a higher CT compared to Naegleria sp. and may require as much attention as Naegleria sp. in recycled water. 
Table 5. Efficacy of chlorine on Legionella pneumophila, viruses and various protozoa.

\begin{tabular}{|c|c|c|c|c|}
\hline Organism & $\begin{array}{c}\text { Temp } \\
\left({ }^{\circ} \mathrm{C}\right)\end{array}$ & pH & $\mathrm{CT}_{99.9 \%}$ & Ref. \\
\hline Giardia lamblia & 25 & 7 & 41 & {$[85]$} \\
\hline Giardia lamblia & 20 & 7 & 62 & {$[85]$} \\
\hline Giardia lamblia & 15 & 7 & 83 & {$[85]$} \\
\hline Giardia lamblia & 10 & 7 & 124 & {$[85]$} \\
\hline Acanthamoeba M3 & 30 & 8 & 12 & {$[38]$} \\
\hline Acanthamoeba M3 (infected with Legionella sp) & 30 & 8 & 5 & {$[38]$} \\
\hline Acanthamoeba S2 & 30 & 8 & 37 & {$[38]$} \\
\hline Acanthamoeba S2 (infected with Legionella sp) & 30 & 8 & 39 & {$[38]$} \\
\hline Acanthamoeba V1 & 30 & 8 & 70 & [38] \\
\hline Acanthamoeba V1 (infected with Legionella $\mathrm{sp}$ ) & 30 & 8 & 82 & {$[38]$} \\
\hline Acanthamoeba M3 & 50 & 8 & 5 & {$[38]$} \\
\hline Acanthamoeba M3 (infected with Legionella sp) & 50 & 8 & 5 & {$[38]$} \\
\hline Acanthamoeba $\mathrm{S} 2$ & 50 & 8 & 5 & {$[38]$} \\
\hline Acanthamoeba S2 (infected with Legionella sp) & 50 & 8 & 5 & {$[38]$} \\
\hline Acanthamoeba $\mathrm{V} 1$ & 50 & 8 & 28 & {$[38]$} \\
\hline Acanthamoeba V1 (infected with Legionella $\mathrm{sp}$ ) & 50 & 8 & 28 & {$[38]$} \\
\hline Acanthamoeba cysts & 25 & 7.35 & 1260 to $6480 *$ & {$[84]$} \\
\hline Naegleria cysts & 25 & 7.35 & 9 to $30 *$ & {$[84]$} \\
\hline A. polyphaga cysts & 25 & ND & $81,000 *$ & {$[82]$} \\
\hline Enterovirus & 25 & $6-9$ & 1 & {$[85]$} \\
\hline Enterovirus & 20 & $6-9$ & 2 & {$[85]$} \\
\hline Enterovirus & 15 & $6-9$ & 3 & {$[85]$} \\
\hline Enterovirus & 10 & $6-9$ & 4 & {$[85]$} \\
\hline Legionella pneumophila & 25 & ND & 210 & {$[83]$} \\
\hline Legionella pneumophila & 43 & ND & 60 & {$[83]$} \\
\hline Legionella pneumophila serogroup 1 & ND & ND & $9 *$ & {$[86]$} \\
\hline L. pneumophila & 30 & 8 & 4 & {$[38]$} \\
\hline L. pneumophila (in Acanthamoeba V1 co-culture) & 30 & 8 & 38 & {$[38]$} \\
\hline L. pneumophila (in Acanthamoeba S2 co-culture) & 30 & 8 & 44 & {$[38]$} \\
\hline L. pneumophila (in Acanthamoeba M3 co-culture) & 30 & 8 & 50 & {$[38]$} \\
\hline L. pneumophila & 50 & 8 & 3 & {$[38]$} \\
\hline L. pneumophila (in Acanthamoeba V1 co-culture) & 50 & 8 & 3 & {$[38]$} \\
\hline L. pneumophila (in Acanthamoeba S2 co-culture) & 50 & 8 & 3 & {$[38]$} \\
\hline L. pneumophila (in Acanthamoeba M3 co-culture) & 50 & 8 & 3 & [38] \\
\hline
\end{tabular}

* Only 2-log reduction (i.e., $\mathrm{CT}_{99 \%}$ ).

Whereas Legionella sp. in environmental samples almost always occurs in the presence of host protozoa, only a few studies have looked at disinfectant efficacy in co-culture with protozoa. Dupuy et al. [38] used chlorine, chlorine dioxide and chloramine as disinfectants. Co-cultured amoeba and L. pneumophila were enumerated by initially centrifuging $(14,000 \mathrm{~g}, 5 \mathrm{~min})$ the sample and vortexing for $1 \mathrm{~min}$ to release intra-trophozoite bacteria. Aliquots of $1,0.1,0.01$, and $0.001 \mathrm{~mL}$ were then plated on non-nutrient agar (NNA) with an E. coli lawn and on BCYE to enumerate protozoa and Legionella sp., respectively. NNA plates were incubated at $25^{\circ} \mathrm{C}$ for 14 days (for amoeba) and BCYE 
plates were incubated at $37^{\circ} \mathrm{C}$ for seven days (for Legionella sp.). Their results confirmed the superior efficacy of chlorine at higher compared to lower temperatures but also showed wide differences in efficacy if both Legionella sp. and amoeba are targeted (Table 5). Efficacy to chlorine disinfection between infected and non-infected Acanthamoeba sp. and/or L. pneumophila was negatively impacted, especially at the lower temperature (i.e., $30^{\circ} \mathrm{C}$ ). Also included in Table 5 are CT values for Giardia lamblia and enterovirus as a point of reference for modeling risk (discussed later). Although both Legionella sp. and amoeba trophozoites have lower CTs than G. lamblia, higher CTs may be required to get rid of amoeba cysts using chlorine.

The high chlorine concentrations under hyperchlorination can corrode the pipes and appurtenances. Use of appurtenances with protective coating, such as sodium silicate and other anti-corrosion agents, has been proposed to reduce corrosion [32]. Other alternatives include the use of plastic-based infrastructure such as polyvinyl chloride.

Typical chlorine residuals in recycled water systems for ten systems surveyed recently in the US are presented in Table 6 . The average chlorine residual was $0.3 \mathrm{mg} / \mathrm{L}$ and the median was $0.15 \mathrm{mg} / \mathrm{L}$. A typical challenge is for utilities to maintain a chlorine disinfectant residual in the recycled water distribution system due to the inherently high organic carbon of the water which can sequester the disinfectant. Loret et al. [87] reported a significant positive correlation between free-living amoebae and dissolved organic matter. The chlorine also became increasingly ineffective in the distribution system as water temperature decreased the further the water flowed from the effluent point and reservoir (Table 6). Although the density of Legionella spp. decreased with distance from the effluent point in a number of cases, the possibility of most Legionella "hiding" in biofilms cannot be ruled out. Once in the biofilms, they become even more protected from the disinfectant and can be periodically released into the bulk water when the biofilm slough off.

An average $\mathrm{pH} 7.3$ and median $\mathrm{pH} 7.6$ was recorded in recycled water distribution systems (Table 6). In general, the lower the $\mathrm{pH}$, the more efficacious the chlorine because chlorine exists in water as hypochlorous acid with a $\mathrm{pKa}$ of 7.6 which at $\mathrm{pH}<7.6$ is in a neutral form (i.e., $\mathrm{HOCl}$ ) whereas at $\mathrm{pH}>7.6$ exists as hypochlorite ion $\left(\mathrm{OCl}^{-}\right)$. Disinfection with chlorine is impacted by $\mathrm{pH}$ as hypochlorite $\left(\mathrm{OCl}^{-}\right)$ions are less biocidal than the hypochlorous acid (i.e., $\left.\mathrm{HOCl} ;[32,85]\right)$. This has operational management implication in cooling systems as they operate in a fairly alkaline range [42]. Recycled water $\mathrm{pH}$ in the reservoir and distribution system monitored for four consecutive days in Texas and Florida increased compared to the effluent [88]. Such increases can ultimately impact continued efficacy of the remaining residual downstream in the system.

Each system is very different in terms of length, total carbon and other parameters and this could affect the rate of chlorine decay. The chlorine data in Table 6 were used to determine chlorine decay in each system with distance, water temperature and TOC as independent variables (Table 7). Also presented was a summary of wastewater treatment technologies and pertinent practices which could impact disinfectant residuals in the distribution system. For CA-2 and CA-3, 87\% of the chlorine dissipation (reflected by the coefficient of determination, $\mathrm{R}^{2}$ ) was explained by the system length and the decay rate was 0.071 and $0.051 \mathrm{mg} \mathrm{Cl} / \mathrm{mile}$, respectively. Water temperatures accounted for $87 \%$ and $94 \%$ of the chlorine decay in the FL-1 and NC system, respectively. Temperature also accounted for some of the disinfectant decay in the CA-1 and FL-5 systems, but only to a relatively small extent. TOC moderately accounted for decay in AZ-8 (61\%), TX-3 (38\%) and CO-5 (35\%). 
Table 6. Distance and physicochemical characteristic effects on chlorine residual and Legionella spp. occurrence in ten reclaimed water systems.

\begin{tabular}{|c|c|c|c|c|c|c|c|}
\hline Site and & Location $^{\text {a }}$ & Distance (Miles) & TOC (mg/L) & pH & Temp $\left({ }^{\circ} \mathrm{C}\right)$ & Free Cl (mg/L) & Legionella (CFU/mL) \\
\hline \multirow{5}{*}{ CA-18 } & Effluent & 0 & $5.0 \pm 0.3$ & $7.6 \pm 0.1$ & $20.5 \pm 0.3$ & $\mathrm{~N} / \mathrm{A}^{\mathrm{b}}$ & $<3$ \\
\hline & Reservoir & 0.004 & $4.8 \pm 0.1$ & $7.7 \pm 0.3$ & $23.1 \pm 0.3$ & $0.1 \pm 0$ & $<3$ \\
\hline & DS1 & 0.3 & $4.9 \pm 0$ & $7.8 \pm 0.3$ & $20.8 \pm 0.2$ & $0.1 \pm 0$ & $<3$ \\
\hline & DS2 & 1.5 & $4.6 \pm 0.1$ & $8.0 \pm 0$ & $21.3 \pm 0.2$ & $0.1 \pm 0$ & 3 \\
\hline & DS3 & 2.5 & $4.7 \pm 0.2$ & $8.2 \pm 0$ & $19.6 \pm 0.1$ & $0.1 \pm 0$ & $46 \pm 19$ \\
\hline \multirow{5}{*}{ FL-1 } & Effluent & 0 & $4.3 \pm 0.1$ & $7.7 \pm 0.1$ & $29.5 \pm 0.1$ & $2.03 \pm 0.06$ & 2300 \\
\hline & Reservoir & 0.05 & $4.1 \pm 0$ & $7.8 \pm 0$ & $28.9 \pm 0.4$ & $1.17 \pm 0.15$ & $<3$ \\
\hline & DS1 & 0.4 & $4.2 \pm 0$ & $7.8 \pm 0$ & $29.1 \pm 0.2$ & $0.55 \pm 0.05$ & $<3$ \\
\hline & DS2 & 1.1 & $3.9 \pm 0$ & $7.8 \pm 0$ & $27.5 \pm 0.2$ & $0.12 \pm 0.03$ & 3 \\
\hline & DS3 & 2.7 & $3.8 \pm 0$ & $8.1 \pm 0.1$ & $27.0 \pm 0.1$ & $0.10 \pm 0$ & $29 \pm 2$ \\
\hline \multirow{5}{*}{$\mathrm{NC}$} & Effluent & 0 & $6.0 \pm 0$ & $7.0 \pm 0$ & $21.1 \pm 0.5$ & $0.65 \pm 0.09$ & 36 \\
\hline & Reservoir & 7.9 & $5.7 \pm 0.1$ & $6.9 \pm 0$ & $16.3 \pm 0.3$ & $0.1 \pm 0$ & 55 \\
\hline & DS1 & 0.8 & $6.0 \pm 0$ & $7.2 \pm 0.1$ & $17.3 \pm 0.4$ & $0.2 \pm 0.03$ & 9 \\
\hline & DS2 & 8.0 & $6.1 \pm 0.2$ & $7.5 \pm 0.1$ & $16.4 \pm 0.1$ & $0.22 \pm 0.03$ & $47 \pm 17$ \\
\hline & DS3 & 9.3 & $6.0 \pm 0$ & $7.1 \pm 0.1$ & $15.8 \pm 0.4$ & $0.67 \pm 0$ & $23 \pm 9$ \\
\hline \multirow{5}{*}{ CA-3 } & Effluent & 0 & $6.8 \pm 0.1$ & $8.2 \pm 0$ & $22.6 \pm 1$ & $1.33 \pm 0.06$ & $660 \pm 300$ \\
\hline & Reservoir & 21.1 & $7.1 \pm 0.1$ & $7.6 \pm 0$ & $24.2 \pm 0.3$ & $0.16 \pm 0.05$ & 9 \\
\hline & DS1 & 11.5 & $7.1 \pm 0.1$ & $8.5 \pm 0.1$ & $23.4 \pm 0.2$ & $1 \pm 0$ & $140 \pm 30$ \\
\hline & DS2 & 17.9 & $7.1 \pm 0.1$ & $7.7 \pm 0$ & $24.7 \pm 0.2$ & $0.21 \pm 0.04$ & $<3$ \\
\hline & DS3 & 26.9 & $6.7 \pm 0$ & $7.5 \pm 0$ & $23.3 \pm 0.9$ & $0.16 \pm 0.02$ & 6 \\
\hline \multirow{5}{*}{ CA-2 } & Effluent & 0 & $6.1 \pm 0.1$ & $7.1 \pm 0.1$ & $23.5 \pm 0.4$ & $0.21 \pm 0.04$ & $<3$ \\
\hline & Reservoir & 0.002 & $7.1 \pm 0.1$ & $6.9 \pm 0$ & $29.6 \pm 0.7$ & $0.21 \pm 0.02$ & $1600 \pm 1100$ \\
\hline & DS1 & 0.63 & $6.4 \pm 0.1$ & $7.2 \pm 0$ & $27.2 \pm 0.2$ & $0.15 \pm 0.03$ & 24 \\
\hline & DS2 & 1.71 & $6.5 \pm 0.1$ & $7.1 \pm 0$ & $24.0 \pm 0.5$ & $0.14 \pm 0.02$ & 45 \\
\hline & DS3 & 2.62 & $6.4 \pm 0.1$ & $7.2 \pm 0$ & $21.3 \pm 0.1$ & $<0.01$ & 3 \\
\hline \multirow{5}{*}{$\mathrm{CO}-5$} & Effluent & 0 & $7.5 \pm 0.1$ & $7.3 \pm 0.1$ & $23.6 \pm 0.9$ & $23.6 \pm 0.9$ & 130 \\
\hline & Reservoir & 0.006 & $7.5 \pm 0.1$ & $9.5 \pm 0$ & $27.8 \pm 0.8$ & $0.15 \pm 0.03$ & $460 \pm 160$ \\
\hline & DS1 & 0.1 & $7.5 \pm 0.1$ & $7.3 \pm 0$ & $22.4 \pm 0.9$ & $0.14 \pm 0.02$ & $810 \pm 340$ \\
\hline & DS2 & 1.3 & $6.3 \pm 0$ & $7.8 \pm 0.1$ & $23.6 \pm 0.4$ & $0.11 \pm 0.01$ & $220 \pm 270$ \\
\hline & DS3 & 2 & $7.4 \pm 0.1$ & $7.3 \pm 0$ & $22.7 \pm 1.0$ & $0.18 \pm 0.02$ & $92 \pm 2$ \\
\hline \multirow{5}{*}{ CA-1 } & Effluent & 0 & $4.9 \pm 0$ & $8.1 \pm 0$ & $26.7 \pm 0.5$ & $0.16 \pm 0.04$ & $<3$ \\
\hline & Reservoir & 0.1 & $5.7 \pm 0$ & $8.6 \pm 0$ & $19.9 \pm 0.2$ & $<0.01$ & $220 \pm 270$ \\
\hline & DS1 & 2.3 & $8.1 \pm 0.1$ & $7.4 \pm 0$ & $21.0 \pm 0.8$ & $0.03 \pm 0.03$ & $3300 \pm 1900$ \\
\hline & DS2 & 4.4 & $6.8 \pm 0.1$ & $7.6 \pm 0$ & $20.2 \pm 0.6$ & $0.14 \pm 0.02$ & 45 \\
\hline & DS3 & 6.9 & $7.4 \pm 0$ & $7.7 \pm 0$ & $22.6 \pm 0.2$ & $0.13 \pm 0.02$ & 12 \\
\hline \multirow{5}{*}{ AZ-8 } & Effluent & 0 & $6.1 \pm 0.1$ & $7.9 \pm 0$ & $15.2 \pm 1.2$ & $0.22 \pm 0.03$ & $<3$ \\
\hline & Reservoir & 0.9 & $2.4 \pm 0$ & $8.4 \pm 0$ & $17.0 \pm 0.2$ & $0.11 \pm 0.04$ & 12 \\
\hline & DS1 & 0.1 & $1.7 \pm 0$ & $8.4 \pm 0$ & $13.9 \pm 0.6$ & $0.04 \pm 0.02$ & 30 \\
\hline & DS2 & 1.2 & $1.7 \pm 0$ & $8.0 \pm 0$ & $13.8 \pm 0.6$ & $0.14 \pm 0.02$ & 3 \\
\hline & DS3 & 2 & $2.0 \pm 0$ & $7.9 \pm 0$ & $13.5 \pm 0.8$ & $0.05 \pm 0$ & $<3$ \\
\hline
\end{tabular}


Table 6. Cont.

\begin{tabular}{|c|c|c|c|c|c|c|c|}
\hline \multicolumn{2}{|c|}{ Site and Location ${ }^{\text {a }}$} & Distance (Miles) & TOC (mg/L) & pH & Temp $\left({ }^{\circ} \mathrm{C}\right)$ & Free Cl (mg/L) & Legionella (CFU/mL) \\
\hline \multirow{5}{*}{ TX-3 } & Effluent & 0 & $7.5 \pm 0.1$ & $7.8 \pm 0.2$ & $22.9 \pm 0.1$ & $0.4 \pm 0.3$ & $120 \pm 130$ \\
\hline & Reservoir & 1.5 & $7.7 \pm 0.1$ & $7.4 \pm 0.1$ & $21.9 \pm 1$ & $0.3 \pm 0.1$ & $500 \pm 310$ \\
\hline & DS1 & 1.9 & $6.4 \pm 0.1$ & $7.3 \pm 0.1$ & $22.5 \pm 0.1$ & $0.08 \pm 0.03$ & 3 \\
\hline & DS2 & 4.9 & $5.5 \pm 0.1$ & $7.3 \pm 0.1$ & $22.1 \pm 0.1$ & $<0.01$ & 3 \\
\hline & DS3 & 6.4 & $4.9 \pm 0.1$ & $7.9 \pm 0$ & $23.0 \pm 0.3$ & $0.06 \pm 0.1$ & 9 \\
\hline \multirow{5}{*}{ FL-5 } & Effluent & 0 & $13.9 \pm 0.2$ & $7.4 \pm 0$ & $28.3 \pm 0.1$ & $1.53 \pm 0.06$ & $870 \pm 990$ \\
\hline & Reservoir & 0.04 & $15.0 \pm 0$ & $7.5 \pm 0$ & $26.9 \pm 0.5$ & $0.48 \pm 0.08$ & $45 \pm 19$ \\
\hline & DS1 & 0.5 & $14.2 \pm 0.1$ & $7.7 \pm 0$ & $24.7 \pm 0.2$ & $0.14 \pm 0.05$ & 33 \\
\hline & DS2 & 3.3 & $8.4 \pm 0.1$ & $7.2 \pm 0$ & $26.2 \pm 0.2$ & $0.08 \pm 0.03$ & $105 \pm 140$ \\
\hline & DS3 & 6.8 & $8.4 \pm 0.1$ & $7.1 \pm 0$ & $27.4 \pm 0.3$ & $0.13 \pm 0.03$ & 45 \\
\hline \multicolumn{2}{|c|}{ Mean } & $6.8^{c}$ & 6.3 & 7.3 & 22.7 & 0.30 & 440 \\
\hline \multicolumn{2}{|c|}{ Median } & $4.6^{c}$ & 6.2 & 7.6 & 22.9 & 0.15 & 94 \\
\hline
\end{tabular}

${ }^{a}$ Sampled in March (CA-18 and TX-3), April (FL-1, FL-5 and NC), May (AZ-8, CA-1, CA-2, CA-3) or July (CO-5) of 2013; ${ }^{\mathrm{b}}$ Not applicable (No chlorination); ${ }^{\mathrm{c}}$ Mean and median of total mile length of each system as opposed to the mean and median of respective sampling points. (Source: [25]).

\subsection{Chlorine Dioxide}

Chlorine dioxide $\left(\mathrm{ClO}_{2}\right)$ is another oxidizing disinfectant of increased importance in recycled water. However, it decomposes readily and presents storage challenges. Thus, where used, it is typically generated onsite for immediate use by slowly adding a strong acid (e.g., sulfuric acid) to sodium chloride solution. Chlorine dioxide impacts microorganisms by disrupting protein synthesis. Walker et al. [89] reported total elimination of Legionella $\mathrm{sp}$. in a hospital water system after treatment with $50-80 \mathrm{mg} / \mathrm{L}$ chlorine dioxide. Its efficacy on Legionella sp. and Acanthamoeba sp. in comparison to Giardia sp. and enterovirus is presented in Table 8. Based on those results, it is more potent than chlorine. It also shows better efficacy on biofilms compared to chlorine [32,89]. Unlike chlorine, its efficacy is less dependent on $\mathrm{pH}$ changes, but, just like chlorine, it is affected by temperature (Table 8). 
Table 7. Chlorine decay in ten recycled water systems.

\begin{tabular}{|c|c|c|c|c|c|}
\hline Site & System Practices a & Characteristic & Decay Model & $\mathbf{R}^{2}$ & Decay Rate \\
\hline \multirow{3}{*}{ CA-18 } & \multirow{3}{*}{$\begin{array}{l}\text { Plant with } 350 \mathrm{MG} / \mathrm{yr} \text { capacity using MBR followed by UV disinfection. } \\
\text { System with drip irrigation. Water has } 1 \text { day shelf-life in the distribution system. }\end{array}$} & Distance & $y=2 E-17 x+0.1$ & 0 & \multirow{3}{*}{0 (No decay) } \\
\hline & & Temperature & $y=3 E-16 x+0.1$ & 0 & \\
\hline & & TOC & $y=7 E-15 x+0.1$ & 0 & \\
\hline \multirow{3}{*}{ FL-1 } & \multirow{3}{*}{$\begin{array}{l}20 \text { MGD sewage plant with 5-stage biological nutrient removal (BNR; i.e., Bardenpho } \\
\text { system) with enhanced removal of nitrogen and phosphorus. System } \\
\text { was well pressurized, and the water was used rapidly (i.e., within 1-3 days). }\end{array}$} & Distance & $\mathrm{y}=1.0424 \mathrm{e}^{-1.04 \mathrm{x}}$ & 0.739 & \multirow{3}{*}{$1.16 \mathrm{mg} \mathrm{Cl} /{ }^{\circ} \mathrm{C}$} \\
\hline & & Temperature & $\mathrm{y}=2 \mathrm{E}-15 \mathrm{e}^{1.1629 \mathrm{x}}$ & 0.870 & \\
\hline & & TOC & $y=8 E-13 e^{6.6594 x}$ & 0.837 & \\
\hline \multirow{3}{*}{$\mathrm{NC}$} & \multirow{3}{*}{$\begin{array}{l}50 \mathrm{MG} / \mathrm{yr} \text { using AS technology. Effluent disinfected with UV and chlorine. } \\
\text { Booster disinfection at the furthest point sampled (i.e., DS3; not included in the decay } \\
\text { model). }\end{array}$} & Distance & $\mathrm{y}=0.4176 \mathrm{e}^{0.134 \mathrm{x}}$ & 0.576 & \multirow{3}{*}{$0.104 \mathrm{mg} /{ }^{\circ} \mathrm{C}$} \\
\hline & & Temperature & $\mathrm{y}=0.104 \mathrm{x}-1.5489$ & 0.940 & \\
\hline & & TOC & $\mathrm{y}=1 \mathrm{E}-0.8 \mathrm{e}^{2.8477 \mathrm{x}}$ & 0.438 & \\
\hline \multirow{3}{*}{ CA-3 } & \multirow{3}{*}{$\begin{array}{l}110 \text { MGD wastewater plant by AS, tertiary treatment and dual media (anthracite/sand) } \\
\text { filtration. System had multiple pressure zones }(40-200 \mathrm{psi}) \text {. }\end{array}$} & Distance & $\mathrm{y}=-0.0505 \mathrm{x}+1.3543$ & 0.872 & \multirow{3}{*}{$0.051 \mathrm{mg} \mathrm{Cl} / \mathrm{mile}$} \\
\hline & & Temperature & $\mathrm{y}=0.3513 \mathrm{x}+8.879$ & 0.387 & \\
\hline & & TOC & $y=-0.2615 x+2.3947$ & 0.008 & \\
\hline \multirow{3}{*}{$\mathrm{CA}-2$} & \multirow{3}{*}{$\begin{array}{l}\text { Facultative ponds (lagoons; } 3 \mathrm{mg} \mathrm{DO} / \mathrm{L} \text { ) followed by multiple ponds with aerators to attain } \\
8-10 \mathrm{mg} \mathrm{DO} / \mathrm{L} \text { ). Water subjected to DAF (at } 70 \text { to } 80 \mathrm{psi} \text { ), creating microbubbles. System } \\
\text { branched but without any dead ends. Reservoir is aerated. Water used within } 2 \text { days or } \\
\text { discharged into river. }\end{array}$} & Distance & $y=-0.0695 x+0.2117$ & 0.8126 & \multirow{3}{*}{$0.07 \mathrm{mg} \mathrm{Cl} / \mathrm{mile}$} \\
\hline & & Temperature & $y=0.0176 x-0.2998$ & 0.424 & \\
\hline & & TOC & $y=0.0383 x-0.1065$ & 0.027 & \\
\hline \multirow{3}{*}{$\mathrm{CO}-5$} & \multirow{3}{*}{$\begin{array}{l}40 \mathrm{MG} / \mathrm{yr} \text { AS with extended aeration (DO to approximately } 1 \mathrm{mg} / \mathrm{L} \text { to drive nitrification. } \\
\mathrm{UV} \text { disinfection (fluence of } 40,635.28 \mathrm{~mJ} / \mathrm{cm}^{2} \text { ) and chlorine gas } \\
\text { (10 to } 15.1 \mathrm{~b} \text { gas/day in } 1000 \mathrm{gal} / \mathrm{min} \text {.) then filtered through a pack of eight cloth filters. } \\
\text { Reservoir was aerated. }\end{array}$} & Distance & $y=0.0087 x+0.1387$ & 0.073 & \multirow{3}{*}{$\begin{array}{l}0.22 \mathrm{mg} \mathrm{Cl} / \mathrm{mg} \text { TOC ( } \mathrm{R}^{2} \text { low due to } \\
\text { other characteristics e.g., heavy } \\
\text { algal growth in reservoir) }\end{array}$} \\
\hline & & Temperature & $y=0.0011 x+0.1718$ & 0.008 & \\
\hline & & TOC & $\mathrm{y}=-0.0287 \mathrm{e}^{0.2211 \mathrm{x}}$ & 0.352 & \\
\hline \multirow{3}{*}{ CA-1 } & \multirow{3}{*}{$\begin{array}{l}16 \text { MGD AS process with an anoxic phase to facilitate nitrification combined } \\
\text { with a fine bubble diffuser. Clarified liquid was filtered through thick anthracite } \\
\text { and coal filtration beds. The filtered water was disinfected with UV (fluence of } 144,000- \\
180,000 \mathrm{~mJ} / \mathrm{cm}^{2} \text { ) before chlorination. }\end{array}$} & Distance & $y=0.0095 x+0.0659$ & 0.145 & \multirow{3}{*}{$\begin{array}{l}0.015 \mathrm{mg} \mathrm{Cl} /{ }^{\circ} \mathrm{C}\left(\mathrm{R}^{2} \text { low due to }\right. \\
\text { other characteristics e.g., multiple } \\
\text { pressure zones with } 14 \text { to } 90 \mathrm{psi})\end{array}$} \\
\hline & & Temperature & $\mathrm{y}=0.0153 \mathrm{x}-0.2456$ & 0.337 & \\
\hline & & TOC & $y=-0.0119 x+0.1703$ & 0.043 & \\
\hline \multirow{3}{*}{ AZ-8 } & \multirow{3}{*}{$\begin{array}{l}\text { Production capacity of } 0.28 \text { MGD. The aeration tanks had an anoxic zone where the mixed } \\
\text { liquor dissolved solids attained a low DO }(0.07 \mathrm{mg} \text { DO/L). Disinfection was achieved with } \\
\text { chlorine gas followed by gravity-fed filtration (sand and anthracite). Distributed through a } \\
\text { looped system. }\end{array}$} & Distance & $y=-0.0353 x+0.1411$ & 0.151 & \multirow{3}{*}{$\begin{array}{l}0.031 \mathrm{mg} \mathrm{Cl} / \mathrm{mg} \text { TOC }\left(\mathrm{R}^{2} \text { low due }\right. \\
\text { to other characteristics e.g., } \\
\text { disinfectant retention by filters) }\end{array}$} \\
\hline & & Temperature & $\mathrm{y}=0.0056 \mathrm{e}^{0.1894 \mathrm{x}}$ & 0.157 & \\
\hline & & TOC & $y=0.0313 x+0.0249$ & 0.609 & \\
\hline
\end{tabular}


Table 7. Cont.

\begin{tabular}{|c|c|c|c|c|c|}
\hline Site & System Practices a & Characteristic & Decay Model & $\mathbf{R}^{2}$ & Decay Rate \\
\hline \multirow{3}{*}{ TX-3 } & \multirow{3}{*}{$\begin{array}{l}60 \text { MGD plant with an activated sludge process. System had some dead ends. The dissolved } \\
\text { oxygen was greatly diminished in the distribution system as well and the water was rusty } \\
\text { due to corrosion. }\end{array}$} & Distance & $\mathrm{y}=0.3058 \mathrm{e}^{-0.745 \mathrm{x}}$ & 0.336 & \multirow{3}{*}{$\begin{array}{l}1.69 \mathrm{mg} \mathrm{Cl} / \mathrm{mg} \text { TOC ( } \mathrm{R}^{2} \text { low due to } \\
\text { other factors e.g., corrosion) }\end{array}$} \\
\hline & & Temperature & $\mathrm{y}=2 \mathrm{E}-15 \mathrm{e}^{1.3472 \mathrm{x}}$ & 0.069 & \\
\hline & & TOC & $y=7 E-07 e^{1.6884 x}$ & 0.377 & \\
\hline \multirow{3}{*}{ FL-5 } & \multirow{3}{*}{$\begin{array}{l}\text { The anaerobic-anoxic-oxic (i.e., A2O) plant had a } 2.75 \text { MGD capacity. The treatment } \\
\text { process removed BOD and TSS as well as reduced nitrogen and phosphorus. }\end{array}$} & Distance & $\mathrm{y}=0.4263 \mathrm{e}^{-0.246 \mathrm{x}}$ & 0.347 & \multirow{3}{*}{$\begin{array}{c}0.304 \mathrm{mg} \mathrm{Cl} /{ }^{\circ} \mathrm{C}\left(\mathrm{R}^{2} \text { low due to }\right. \\
\text { other characteristics e.g., multiple } \\
\text { dead ends and pressure zones) }\end{array}$} \\
\hline & & Temperature & $y=0.3041 x-7.6502$ & 0.457 & \\
\hline & & TOC & $\mathrm{y}=0.137 \mathrm{e}^{0.2437 \mathrm{x}}$ & 0.421 & \\
\hline
\end{tabular}

a $\mathrm{AS}=$ Activated sludge; $\mathrm{BNR}=$ biological nutrient removal; $\mathrm{MG}=$ Million gallons; $\mathrm{MBR}=$ membrane bioreactor; DAF $=$ dissolved air floatation; DO $=$ dissolved oxygen. 
Table 8. Efficacy of chlorine dioxide on Legionella pneumophila, viruses and various protozoa.

\begin{tabular}{|c|c|c|c|c|}
\hline Organism & Temp $\left({ }^{\circ} \mathrm{C}\right)$ & pH & CT $99.9 \%$ & Ref. \\
\hline Giardia lamblia & 25 & $6-9$ & 11 & [85] \\
\hline Giardia lamblia & 20 & $6-9$ & 15 & [85] \\
\hline Giardia lamblia & 15 & $6-9$ & 19 & [85] \\
\hline Giardia lamblia & 10 & $6-9$ & 23 & [85] \\
\hline Acanthamoeba M3 & 30 & 8 & 0.5 & [38] \\
\hline Acanthamoeba M3 (infected with Legionella sp) & 30 & 8 & 0.5 & [38] \\
\hline Acanthamoeba $\mathrm{S} 2$ & 30 & 8 & $2.1 *$ & [38] \\
\hline Acanthamoeba S2 (infected with Legionella sp) & 30 & 8 & $5.5 *$ & [38] \\
\hline Acanthamoeba $\mathrm{V} 1$ & 30 & 8 & $0.4 *$ & [38] \\
\hline Acanthamoeba V1 (infected with Legionella sp) & 30 & 8 & $3.5 *$ & [38] \\
\hline Vermamoeba vermiformis & 20 & 7.6-7.8 & $300 *$ & [90] \\
\hline Enterovirus & 25 & $6-9$ & - & [85] \\
\hline Enterovirus & 20 & $6-9$ & 6.4 & [85] \\
\hline Enterovirus & 15 & $6-9$ & 8.6 & [85] \\
\hline Enterovirus & 10 & $6-9$ & 12.8 & [85] \\
\hline Legionella sp. & ND & ND & 0.08 & [91] \\
\hline Legionella pneumophila & 30 & 8 & 0.4 & [38] \\
\hline L. pneumophila (in Acanthamoeba V1 co-culture) & 30 & 8 & 2.8 & [38] \\
\hline L. pneumophila (in Acanthamoeba S2 co-culture) & 30 & 8 & $0.9 * *$ & [38] \\
\hline L. pneumophila (in Acanthamoeba M3 co-culture) & 30 & 8 & 2.4 & [38] \\
\hline
\end{tabular}

\subsection{Monochloramine}

From a practical perspective, monochloramine can be locally generated by adding free chlorine in a solution of ammonium chloride at a chlorine to nitrogen molar ratio of $0.5 \mathrm{(pH} \mathrm{8.5).} \mathrm{Also} \mathrm{formed} \mathrm{during}$ the process are dichloramine and nitrogen trichloramine. However, monochloramine is generally most predominant of the three at neutral $\mathrm{pH}$ or higher [32]. The three products are commonly referred to as "combined" chlorine. Disinfection with chloramine gained traction in the US because the disinfectant is more stable in the system, minimizes the formation of disinfection by-products, and can penetrate biofilms better compared to free chlorine [15]. Its efficacy against Legionella sp. was demonstrated in various systems [15,92]. In a different study, monochloramine concentrations of $1-4 \mathrm{mg} / \mathrm{L}$ as $\mathrm{Cl}_{2}$ significantly reduced the occurrence of Legionella sp. in a hospital water system [93]. The wide range of monochloramine concentrations required was possibly due to $\mathrm{pH}$ as disinfection with chloramine requires an optimal $\mathrm{pH}$ of approximately 7.5. Its use led to a less diverse Legionella spp. population in the distribution system of water with a high average TOC content of $4 \mathrm{mg} / \mathrm{L}$ [17]; typical of recycled water. The occurrence of Legionella sp. in showerheads and cooling towers on switching from chlorine to chloramine decreased from $20 \%$ to $6.2 \%$ although the density of L. pneumophila (detected via $16 \mathrm{~S}$ rRNA and direct culturing) remained the same, suggesting resistance of this species to chloramine.

From an epidemiologic perspective, US hospitals supplied with water disinfected with chlorine were more likely to have reported outbreak of Legionnaires' disease than hospitals that used monochloramine as a 
disinfectant (odds ratio 10.2 [95\% confidence interval 1.4-460]; Kool et al., [15]). This implied that hospitals supplied with water containing free chlorine were 10.2 times more likely to experience a Legionnaires' disease outbreak. However, that study was entirely based on infections and not substantiated by field data on the occurrence of Legionella sp. in the studied areas.

The efficacy of chloramine to Legionella sp. and amoeba in comparison to Giardia lamblia and enteroviruses is summarized in Table 9. Those data show much lower CTs for Legionella sp. and amoeba compared to G. lamblia and enteroviruses even in instances where the Legionella sp. are embedded in amoeba.

Table 9. Efficacy of chloramine on Legionella pneumophila, viruses and various protozoa.

\begin{tabular}{|c|c|c|c|c|}
\hline Organism & Temp $\left({ }^{\circ} \mathrm{C}\right)$ & $\mathbf{p H}$ & CT $99.9 \%$ & Ref. \\
\hline Giardia lamblia & 25 & $6-9$ & 750 & [85] \\
\hline Giardia lamblia & 20 & $6-9$ & 1100 & [85] \\
\hline Giardia lamblia & 15 & $6-9$ & 1500 & [85] \\
\hline Giardia lamblia & 10 & $6-9$ & 1850 & [85] \\
\hline Acanthamoeba M3 & 30 & 8 & 19 & [38] \\
\hline Acanthamoeba M3 (infected with Legionella sp) & 30 & 8 & 20 & [38] \\
\hline Acanthamoeba $\mathrm{S} 2$ & 30 & 8 & $40 *$ & [38] \\
\hline Acanthamoeba S2 (infected with Legionella sp) & 30 & 8 & $47 *$ & [38] \\
\hline Acanthamoeba V1 & 30 & 8 & 23 & [38] \\
\hline Acanthamoeba V1 (infected with Legionella sp) & 30 & 8 & 24 & [38] \\
\hline Enterovirus & 25 & $6-9$ & 356 & [85] \\
\hline Enterovirus & 20 & $6-9$ & 534 & [85] \\
\hline Enterovirus & 15 & $6-9$ & 712 & [85] \\
\hline Enterovirus & 10 & $6-9$ & 1067 & [85] \\
\hline Legionella pneumophila & 30 & 8 & 17 & [38] \\
\hline L. pneumophila (in Acanthamoeba V1 co-culture) & 30 & 8 & 23 & [38] \\
\hline L. pneumophila (in Acanthamoeba S2 co-culture) & 30 & 8 & 22 & [38] \\
\hline L. pneumophila (in Acanthamoeba M3 co-culture) & 30 & 8 & 19 & [38] \\
\hline
\end{tabular}

\subsection{Ozone}

Ozone has been used to inactivate microorganisms in recycled water for almost three decades [94-96]. Ozone attacks unsaturated bonds of aldehydes, ketones, and carbonyl compounds [97] and can participate in electrophilic reactions with aromatic compounds and neutrophilic reactions with many cellular components (i.e., fatty acids, carbohydrates, amino acids, proteins, and nucleic acids). These reactions collectively affect the cytoplasmic membrane of bacterial cells and the protein structure as well as DNA. However, because it does not form a stable residual, it decomposes rapidly in the water. Thus, it is typically used by the recycled water industry in combination with other disinfectants (Figure 4).

Muraca et al. [83] provided $0.5 \mathrm{mg}$ ozone/L, reducing L. pneumophila in 5 h by 5 log units from an initial concentration of $10^{7} \mathrm{cfu} / \mathrm{mL}$ (Table 10). Ozone efficacy was not impacted by temperature $\left(25^{\circ} \mathrm{C}\right.$ versus $43{ }^{\circ} \mathrm{C}$ ) or turbidity although the level of turbidity was not quantified. Temperatures above $30{ }^{\circ} \mathrm{C}$ occur rarely in US recycled water distribution systems (Table 6) but can be encountered in cooling 
towers. Based on Domingue et al. [86], the efficacy of ozone was not greatly affected by $\mathrm{pH}$ or temperature although others reported better efficacy against coliphage and bacteria at lower temperatures [98]. CT values from Muraca et al. [83] for reducing Legionella sp. were much higher than those reported by others possibly because that research group dosed their system as to maintain an ozone residual of 1 to $2 \mathrm{mg} / \mathrm{L}$.

Much lower CT values are required to control both Naegleria and Acanthamoeba cysts with ozone at $25^{\circ} \mathrm{C}$ although slightly high CTs may be required at lower temperatures of $20-22{ }^{\circ} \mathrm{C}$ (Table 10). Overall, ozone is more effective than chlorine dioxide, which was in turn more effective than chlorine (i.e., $\mathrm{O}_{3}>$ $\mathrm{ClO}_{2}>\mathrm{Cl}_{2}$ ); an observation that is in agreement with Miller and Simpson [42]. However, since ozone dissipates from the water much more quickly, it should preferably be used in combination with chlorine or chloramine to serve as a preservative.

Table 10. Efficacy of ozone on Legionella pneumophila, viruses and various protozoa.

\begin{tabular}{lcccc}
\hline \multicolumn{1}{c}{ Organism } & Temp $\left({ }^{\circ} \mathbf{C}\right)$ & pH & CT 99\% (mg min/L) & Ref. \\
\hline Giardia lamblia & 25 & $6-9$ & $0.48 *$ & {$[85]$} \\
Giardia lamblia & 20 & $6-9$ & $0.72 *$ & {$[85]$} \\
Giardia lamblia & 15 & $6-9$ & $0.95 *$ & {$[85]$} \\
Giardia lamblia & 10 & $6-9$ & $1.4 *$ & {$[85]$} \\
Naegleria gruberi $(\mathrm{NEG)}$ & 25 & 7 & 1.3 & {$[99]$} \\
Naegleria gruberi (NEG) & 25 & 7 & $<1.6$ & {$[100]$} \\
Naegleria gruberi (1518/1d) & 25 & 7 & 1.6 & {$[100]$} \\
Naegleria gruberi (Echirolles) & 25 & 7 & $<1.6$ & {$[100]$} \\
Naegleria spp. (MO5; C110; An24) & 25 & 7 & $<1.6$ & {$[100]$} \\
Naegleria fowleri & 25 & 7 & $<1.6$ & {$[100]$} \\
Acanthamoeba polyphaga (1501/3a) & 25 & 7 & 2.5 & {$[100]$} \\
Acanthamoeba polyphaga & $20-22$ & $7.5-8$ & 5 & {$[101]$} \\
Acanthamoeba culbertsoni (A1) & 25 & 7 & $<1.6$ & {$[100]$} \\
Acanthamoeba royreba $($ OR) & 25 & 7 & $<1.6$ & {$[100]$} \\
Acanthamoeba spp. (MR4) & 25 & 7 & 1.6 & {$[100]$} \\
Hartmannella vermiformis & 25 & ND & $<1.6$ & {$[100]$} \\
Enterovirus & 25 & $6-9$ & 0.15 & {$[85]$} \\
Enterovirus & 20 & $6-9$ & 0.25 & {$[85]$} \\
Enterovirus & 15 & $6-9$ & 0.3 & {$[85]$} \\
Enterovirus & 10 & $6-9$ & 0.5 & {$[85]$} \\
Legionella pneumophila & 25 & ND & 60 & {$[83]$} \\
Legionella pneumophila & 43 & ND & 55 & {$[83]$} \\
Legionella pneumophila serogroup 1 & $25-45$ & 7.2 & 0.5 & {$[86]$} \\
Legionella pneumophila serogroup 1 & 25 & 8 & 0.95 & {$[86]$} \\
Legionella pneumophila serogroup 1 & 25 & 8.9 & $0.65 *$ & {$[86]$} \\
\hline
\end{tabular}

ND: Not determined; * $\mathrm{CT}_{99.9}$ data.

\section{6. $U V$}

UV does not kill microorganisms but rather damage their DNA, which prevents them from reproducing. Preventing reproduction in turn prevents infectivity. Similar to the CT concept, UV 
intensity $\left(\mathrm{mW}-\mathrm{s} / \mathrm{cm}^{2}\right)$ times the exposure time(s) commonly referred to as fluence $\left(\mathrm{mJ} / \mathrm{cm}^{2}\right)$ describes UV disinfection capability. Fluence represents the energy per unit area falling onto a surface. Maximum efficacy with UV is attained at $254 \mathrm{~nm}$ [32] but turbidity, natural organic matter content and particulate matter can significantly affect UV disinfection capability. UV irradiation at $30 \mathrm{~mJ} / \mathrm{cm}^{2}$ reduced $L$. pneumophila by $5 \log$ units in $20 \mathrm{~min}$ ([83]; Table 11). Continued exposure to this dose for $6 \mathrm{~h}$ still left a residual of $10^{2} \mathrm{cfu} / \mathrm{mL}$. Schwartz et al. [102] detected Legionella sp. in biofilms formed on polyethylene, polyvinyl chloride (PVC), and stainless steel coupons following disinfection with UV but no Legionella sp. was detected on copper coupons. UV disinfection was not affected by temperature. UV efficacy was also independent of $\mathrm{pH}$ [103]. Legionella sp. was inactivated within 3 min on exposure to ultraviolet light at $90 \mathrm{~mJ} / \mathrm{cm}^{2}$ [81]. All Legionella isolates tested by Cervero-Aragó et al. [104] required 5-6 mJ/ $\mathrm{cm}^{2} \mathrm{UV}$ fluence to inactive 4 logs. However, a higher fluence was required when co-cultured with amoeba (Table 11).

Table 11. Efficacy of UV on Legionella pneumophila, in comparison with Giardia and enterovirus.

\begin{tabular}{|c|c|c|c|c|c|}
\hline \multirow[t]{2}{*}{ Organism } & \multicolumn{4}{|c|}{$\begin{array}{c}\text { Fluency }\left(\mathbf{m J} / \mathrm{cm}^{2}\right) \text { for Respective } \\
\text { Inactivation }\end{array}$} & \multirow[t]{2}{*}{ Ref. } \\
\hline & $1 \mathrm{Log}$ & 2 Logs & 3 Logs & 4 Logs & \\
\hline Giardia & & & 11 & & [103] \\
\hline Giardia & & & $20-80$ & & {$[105]$} \\
\hline Giardia & & $<10$ & & & {$[105]$} \\
\hline Acanthamoeba sp. & 40 & & & & [106] \\
\hline A. castellani CCAP 1534/2 (Trophozoites) & 32.1 & & 22.7 & & {$[104]$} \\
\hline A. castellani CCAP 1534/2 (Cysts) & 45.4 & & 90.9 & & [104] \\
\hline Acathamoeba sp. 155 (Trophozoites) & 27.6 & & 65.7 & & [104] \\
\hline Acathamoeba sp. 155 (Cysts) & 34.2 & & 99.2 & & [104] \\
\hline V. vermiformis CCAP 1534/7A (Trophozoites) & 10.7 & & 26 & & [104] \\
\hline V. vermiformis CCAP 1534/7A (Cysts) & 16.8 & & 53.8 & & [104] \\
\hline V. vermiformis 195 (Trophozoites) & 10.1 & & 24.2 & & [104] \\
\hline V. vermiformis 195 (Cysts) & 31.5 & & 76.2 & & [104] \\
\hline Enterovirus & & & & 186 & [103] \\
\hline Legionella pneumophila sg. 1 ATCC 33152 & 1.7 & & & 5.7 & [104] \\
\hline Legionella pneumophila sg. $1 \mathrm{env}^{\mathrm{a}}$ & 1.7 & & & 5 & [104] \\
\hline Legionella pneumophila sg. 7 ATCC 33823 & 1.7 & & & 5 & [104] \\
\hline Legionella pneumophila sg. 8 env ${ }^{\text {a. }}$ & 1.8 & & & 6.1 & [104] \\
\hline Legionella pneumophila ATCC 33462 & 1.4 & & & 6.3 & [104] \\
\hline Legionella pneumophila sg. 1 env & & & 4 & & {$[104]$} \\
\hline $\begin{array}{l}\text { Legionella pneumophila sg. } 1 \text { env with } \\
\text { A. castellani CCAP } 1534 / 2\end{array}$ & & & 6 & & {$[104]$} \\
\hline $\begin{array}{l}\text { Legionella pneumophila sg. } 1 \text { env with } \\
\text { Acathamoeba sp. } 155\end{array}$ & & & 8 & & {$[104]$} \\
\hline Legionella pneumophila $\left(25^{\circ} \mathrm{C}\right.$ and $\left.43^{\circ} \mathrm{C}\right)$ & & & 30 & & [83] \\
\hline
\end{tabular}

a L. pneumophila sg. 1 env and L. pneumophila sg. 8 env were environmental isolates.

Hijnen et al. [106] reported a log reduction of Acanthamoeba sp. with $40 \mathrm{~mJ} / \mathrm{cm}^{2}$, a fluence sufficient for impacting adenoviruses as well. Three log units of various Acanthamoeba species and $V$. vermifomis 
were inactivated with 23 to $100 \mathrm{~mJ} / \mathrm{cm}^{2} \mathrm{UV}$, the higher fluence being required for cyst inactivation (Table 11). Overall, inactivation of Acanthamoeba sp. and Vermamoeba veriformis required higher levels of UV compared to Giardia sp. Generally, UV light is most effective on protozoa followed by bacteria and least effective against viruses. However, this generalization does not seem to apply to Legionella sp. as high fluence was required by Muraca et al. [83] for any impact (Table 11). Because UV does not provide a residual, it is typically combined with a chemical disinfectant ion for effectively controlling Legionella sp.

\subsection{Copper-Silver Ionization}

Both copper and silver have biocidal activity. In ionization chambers, both metals can be ionized through electrolysis forming positively charged ions of each metal. The copper ions form electrostatic compounds with negatively charged cell walls of Legionella sp. (and other bacteria), disrupting cell wall permeability and subsequent nutrient uptake. The ions penetrate the cell wall and create an entrance for silver ions $\left(\mathrm{Ag}^{+}\right)$which penetrate the cells and bond with DNA, RNA, cellular proteins and respiratory enzymes, immobilizing the cell and curtailing cell division. This chain of events leads to death. Thus, combining both metal ions has a synergistic effect. Copper-silver ionization has been widely used to control Legionella sp. in various settings [22]. The technology was quite effective against Legionella sp. at copper-silver ionization concentrations of $0.36 / 0.04 \mathrm{mg} / \mathrm{L}$ but slightly higher concentrations of 0.4/0.04 may be required in large systems. The metals also effectively penetrated the biofilm. However, $\mathrm{Cu}-\mathrm{Ag}$ ionization efficacy can be impacted by water $\mathrm{pH}$ and TDS. With $\mathrm{pH} 9$, only one tenth of all Legionella sp. were eliminated. The silver will precipitate in the presence of high dissolved solid concentrations becoming unavailable for disinfection. Most studies have looked at the disinfection effects of these ions used together but Lin et al. [107] examined the effects of each ion individually. They reported complete inactivation of L. pneumophila serotype 1 in $2.5 \mathrm{~h}$ (6 log reduction) with $0.1 \mathrm{mg} / \mathrm{L}$ copper. Similarly, L. pneumophila was killed within $6 \mathrm{~h}$ on exposure to a solution of $50 \mu \mathrm{g} / \mathrm{L}$ silver ions [80].

\subsection{Other Disinfecting Agents}

Bromine as a disinfectant behaves in a similar fashion as chlorine, existing in water as hypobromous acid $(\mathrm{HOBr})$ and hypobromite ion $\left(\mathrm{OBr}^{-}\right)$depending on the $\mathrm{pH}$ [32]. At neutral $\mathrm{pH}, \mathrm{HOBr}$ is the predominant species ( $\mathrm{pKa}$ of 8.8 which is a unit higher than chlorine). Bromine has generally less efficacy against Legionella sp. compared to chlorine. Bromine at CT $=576$ to $1440 \mathrm{mg} \mathrm{min} / \mathrm{L}$, iodine at CT $=2880$ to $7200 \mathrm{mg} \mathrm{min} / \mathrm{L}$, and iodophore at $\mathrm{CT}=2880$ to $7200 \mathrm{mg} \mathrm{min} / \mathrm{L}$ ) were ineffective against Acanthamoeba culbertsoni cysts at pH 7.5 [84]. By contrast, these CT values with iodine and ionophore had acceptable cysticidal effect on Neagleria fowleri. Although used for potable water disinfection in some instances, use of bromine, iodine and hydrogen peroxide in recycled water systems has not been documented. Other disinfectants and their related efficacy to Legionella sp. and protozoa are summarized in Table 10. Miller and Simpson [42] reaffirmed the resistant nature of protozoa cysts to disinfection with some of these disinfectants as well.

Like hydrogen peroxide, peracetic acid $\left(\mathrm{CH}_{3} \mathrm{COOOH}\right)$ is another peroxygen compound but with even higher potency that has not yet been exploited by the recycled water industry. It is thought to disinfect 
by impacting lipoproteins in the cell membrane [108]. Unlike chlorine and hydrogen peroxide, its potency is not greatly compromised by presence of organic matter or enzymes, respectively [109]. Although most effective against fecal indicator bacteria and viruses under mildly acidic conditions, it showed acceptable potency at neutral $\mathrm{pH}$ as well. It was also more effective against biofilms [108]. Peracetic acid has not been used to control Legionella sp. but was used against Acanthamoeba sp. and Naegleria sp. at different concentrations (Table 12). Its efficacy was more elevated in a combination of $0.2 \%$ PAA and $80 \%$ ethanol [110].

Table 12. Minimum lethal concentration of various biocides on protozoa.

\begin{tabular}{|c|c|c|c|c|c|c|c|c|}
\hline \multirow{3}{*}{ Biocide } & \multicolumn{8}{|c|}{ Minimum Lethal Dose (MLC; mg/L) } \\
\hline & \multicolumn{2}{|c|}{ Acanthamoeba } & \multicolumn{2}{|c|}{ Naegleria } & \multicolumn{2}{|c|}{ Colpoda } & \multirow[t]{2}{*}{ Tetrahymena } & \multirow[t]{2}{*}{ Vannella } \\
\hline & Trophozoite & Cyst & Trophozoite & Cyst & Trophozoite & Cyst & & \\
\hline Peracetic acid $^{\text {a }}$ & 15 & 150 & 8 & 8 & ND & ND & ND & ND \\
\hline $\begin{array}{c}\text { Chlorinated phenolic } \\
\text { thioether }^{\mathrm{a}}\end{array}$ & 10 & 80 & 2 & 20 & ND & ND & ND & ND \\
\hline Isothiazolin $^{\text {a }}$ & 2 & 150 & $<1$ & 2 & ND & ND & ND & ND \\
\hline Isothiazolin $^{\mathrm{b}}$ & 244 & 31,250 & ND & ND & 31 & 7813 & 31 & 122 \\
\hline $\begin{array}{c}\text { Polyhexamethylene } \\
\text { biguanide }^{\mathrm{a}}\end{array}$ & 10 & 5 & 20 & 2000 & ND & ND & ND & ND \\
\hline Bromonitropropanediol $^{\text {a }}$ & 200 & $>10,000$ & 50 & 25 & ND & ND & ND & ND \\
\hline Methylenebis thiocyanate $^{a}$ & 3 & $>1000$ & 5 & $<1$ & ND & ND & ND & ND \\
\hline Thiocarbamate $^{\mathrm{b}}$ & 3906 & 125,000 & ND & ND & 977 & 31,250 & 244 & 3906 \\
\hline $\begin{array}{l}\text { Quaternary ammonium } \\
\text { compounds (QAC) }^{\mathrm{b}}\end{array}$ & 61 & 62,500 & ND & ND & 61 & 488 & 122 & 61 \\
\hline $\begin{array}{l}\text { Tributyltin neodecanoate } \\
\text { (TBT)/QAC }{ }^{\mathrm{b}}\end{array}$ & 31 & 122 & ND & ND & 15 & 31 & 15 & 61 \\
\hline Chlorine $^{\mathrm{a}}$ & 2 & $>50$ & 2 & 4 & ND & ND & ND & ND \\
\hline
\end{tabular}

Berk et al. [34] tested Microbiocides MBC-115 and MBC-215 widely used in cooling towers to control Legionella spp. at final concentrations of $15 \mathrm{ppm}$ ( $\mathrm{vol} / \mathrm{vol})$ and $100 \mathrm{ppm}$ ( vol/vol), respectively to control amoeba. MBC-115 is a quaternary ammonium comprised of poly[oxyethylene (dimethyliminio)ethylene (dimethyliminio)ethylene dichloride (Nash-Chem, Nashville, TN). Its efficacy on Legionella spp. was dismal. MBC-215 is an isothiazine derivative of a mixture of 5-chloro-2-methyl-4-isothiazolon-3-one and 2-methyl-4-isothiazolin (Nash-Chem, Nashville, TN, USA). The concentration used was also ineffective on Legionella spp. However, efficacy of these microbiocides against Legionella spp. may be impacted by the conditions under which the target organism is growing. For example, polyhexamethylene bioguanide and benzisothiazolone were ineffective against L. pneumophila grown with A. polyphaga compared to L. pneumophila pure cultures [112]. Both microbiocides act by impacting the integrity of the bacteria cell membrane. The presence of amoebal proteins coating Legionella seems to confer biocide resistance.

Iron is a fundamental requirement for Legionella spp. but these organisms lack siderophores which are capable of competing with iron chelators. Thus, addition of lactoferrin, an iron chelator sequestered this essential nutrient, killing L. pneumophila [113]. The economic feasibility of this strategy to control 
Legionella $\mathrm{sp}$. in full-scale recycled water treatment systems is unknown. On the opposite extreme, excessive amounts of iron inhibited biofilm formation [114]. Raftery et al. [115] documented reduced formation of L. pneumophila biofilms with nanoparticles. Interaction between L. pneumophila and amoeba in the presence of gold nanoparticels was also negatively impacted. These metal and nanoparticle considerations have not yet been fully explored as possible management strategy for Legionella sp. and protozoa in recycled water.

\section{Summary and Conclusions}

Whereas Legionella sp. in environmental samples almost always occurs in the presence of host protozoa, only a few studies have looked at disinfectant efficacy in co-culture with protozoa. Utilities typically face challenges in maintaining a disinfectant residual in the recycled water distribution system due to the inherently high organic carbon of the water, which can sequester the disinfectant. Furthermore, some Legionella strains may be inherently resistant to common disinfectants such as chloramine. Overall, use of a combination of disinfectants, e.g., UV combined with chlorination or ozone combined with chlorine is more likely to produce a more acceptable product. Some emerging disinfectants such as peracetic acid appear less prone to dissipation in the presence of organic matter. More research is needed to establish their efficacy in recycled water and the associated economics of use in full-scale systems. Legionella outbreaks tend to occur sporadically and in most instances the source of infection is not always easily deciphered. Although no outbreak has been associated with recycled water, the industry needs to proactively prevent future outbreaks. Studies to understand the role played by protozoa in establishing the infectious dose of Legionella spp. to humans need to be conducted.

\section{Acknowledgments}

The authors are grateful to the WateReuse Research Foundation for funding the study under project funding agreement WateReuse-12-05 (Managed for the Foundation by Stefani McGregor) and the utility subsidiaries of American Water, Voorhees, NJ, USA.

\section{Author Contributions}

Patrick K. Jjemba carried out the literature review, data extraction and analysis. William Johnson developed the initial topic outline and identified some review material. Zia Bukhari and Mark W. LeChevallier edited the initial draft and identified additional literature sources.

\section{Conflicts of Interest}

The authors declare no conflict of interest.

\section{References}

1. US EPA (United States Environmental Protection Agency). Drinking Water Candidate Contaminant List and Regulatory Determinations. Available online: http:/water.epa.gov/scitech/drinkingwater/ dws/ccl/ccl3.cfm (accessed on 8 February 2015). 
2. Jjemba, P.K.; Bukhari, Z.; LeChevallier, M.W. Examination of Microbiological Methods for Use in Reclaimed Waters: Comprehensive Report; WateReuse Foundation: Alexandria, VA, USA, 2013.

3. Birks, R.; Colbourne, J.; Hills, S.; Hobson, R. Microbiological water quality in a large in-building, water recycling facility. Water Sci. Technol. 2004, 50, 165-172.

4. Ajibode, O.M.; Rock, C.; Bright, K.; McLain, J.E.T.; Gerba, C.P.; Pepper, I.L. Influence of residence time of reclaimed water within distribution systems on water quality. J. Water Reuse Desal. 2013, 3, 185-196.

5. Buse, H.Y.; Lu, J.; Ashbolt, N.J. Exposure to synthetic gray water inhibits amoeba encystation and alters expression of Legionella pneumophila virulence genes. Appl. Environ. Microbiol. 2015, 81, 630-639.

6. Kool, J.L.; Warwick, M.C.; Pruckler, J.M.; Brown, E.W.; Butler, J.C. Outbreak of Legionnaires' disease at a bar after basement flooding. Lancet 1998, 351, 1030.

7. White, P.S.; Graham, F.F.; Harte, D.J.G.; Baker, M.G.; Ambrose, C.D.; Humphrey, A.R.G. Epidemiological investigation of a Legionnaires' disease outbreak in Christchurch, New Zealand: The value of spatial methods for practical public health. Epidemiol. Infect. 2013, 141, 789-799.

8. Engelhart, S.; Pleischl, S.; Luck, C.; Marklein, G.; Fischnaller, E.; Martin, S.; Exner, M. Hospital-acquired legionellosis originating from a cooling tower during a period of thermal inversion. Int. J. Hyg. Environ. Health 2008, 211, 235-240.

9. Yiallouros, P.K.; Papadouri, T.; Karaoli, C.; Papamichael, E.; Zeniou, M.; Pieridou-Bagatzouni, D.; Papageorgiou, G.T.; Pissarides, N.; Harrison, T.; Hadjidemetriou, A. First outbreak of nosocomial Legionella infection in term neonates caused by a cold mist ultrasonic humidifier. Clin. Infect. Dis. 2013, 57, 48-56.

10. Cohn, P.D.; Gleason, J.A.; Rudowski, E.; Tsai, S.M.; Genese, C.A.; Fagliano, J.A. Community outbreak of legionellosis and an environmental investigation into a community water system. Epidemiol. Infect. 2015, 143, 1322-1331.

11. Neil, K.; Berkelman, R. Increasing incidence of Legionellosis in the United States, 1990-2005: Changing epidemiologic trends. Clin. Infect Dis. 2008, 47, 591-599.

12. Centers for Disease Control and Prevention (CDC). Increasing incidence of legionellosis in the United States, 2000-2009. MMRW 2011, 60, 1083-1086.

13. Yarom, R.; Sheinman, R.; Armon, R. Legionella pneumophila serogroup 3 prevalence in drinking water survey in Israel (2003-2007). Water Sci. Technol. Water Supply 2010, doi:10.2166/ws.2010.489.

14. Lam, M.C.; Ang, L.W.; Tan, A.L.; James, L.; Goh, K.T. Epidemiology and control of Legionellosis, Singapore. Emerg. Inf. Dis. 2011, 17, 1209-1215.

15. Kool, J.L.; Carpenter, J.C.; Fields, B.S. Effect of monochloramine disinfection of municipal drinking water on risk of nosocomial Legionnaires' disease. Lancet 1999, 353, 272-277.

16. Colbourne, J.S.; Dennis, F.J.; Lee, J.V.; Bailey, M.R. Legionnaires' disease: Reduction in risk associated with foaming in evaporative cooling towers. Lancet 1987, 8534, 684.

17. Pryor, M.; Springthorpe, S.; Riffard, S.; Brooks, T.; Huo, Y.; Davis, G.; Sattar, S.A. Investigation of opportunistic pathogens in municipal drinking water under different supply and treatment regimes. Water Sci. Technol. 2004, 50, 83-90. 
18. Loret, J.-F.; Greub, G. Free-living amoebae: Biological by-passes in water treatment. Int. J. Hyg. Environ. Health 2010, 213, 167-175.

19. Serrano-Suárez, A.; Dellundé, J.; Salvadó, H.; Cervero-Aragó, S.; Méndez, J.; Canals, O.; Blanco, S.; Arcas, A.; Araujo, R. Microbial and physicochemical parameters associated with Legionella contamination in hot water recirculation systems. Environ. Sci. Pollut. Res. 2013, doi:10.1007/s11356-013-1557-5.

20. Wang, H.; Edwards, M.; Falkinham, J.O., III; Pruden, A. Molecular survey of the occurrence of Legionella spp., Mycobacterium spp., Pseudomonas aeruginosa, and amoeba hosts in two chloraminated drinking water distribution systems. Appl. Environ. Microbiol. 2012, 87, 6285-6294.

21. Yamamoto, H.; Sugiura, M.; Kusunoki, S.; Ezaki, T.; Ikedo, M.; Yabuuchi, E. Factors stimulating propagation of legionellae in cooling tower water. Appl. Environ. Microbiol. 1992, 58, 1394-1397.

22. Liu, Z.; Stout, J.E.; Boldin, M.; Rugh, J.; Diven, W.F.; Yu, V.L. Intermittent use of copper-silver ionization for Legionella control in water distribution systems: A potential option in buildings housing individuals at low risk of infection. Clin. Infect. Dis. 1998, 26, 138-140.

23. Armstrong, T.W.; Haas, C.N. Legionnaires' disease: Evaluation of a quantitative microbial risk assessment model. J. Water Health 2008, 6, 149-166.

24. Lucas, C.E.; Brown, E.; Fields, B.S. Type IV pili and type II secretion play a limited role in Legionella pneumophila biofilm colonization and retention. Microbiology 2006, 152, 3569-3573

25. Jjemba, P.K.; Johnson, W.; Bukhari, Z.; LeChevallier, M.W. Develop Best Management Practices to Control Potential Health Risks and Aesthetic Issues Associated with Reclaimed Water Storage and Distribution. WateReuse Research Foundation Report (WateReuse-11-03); WateReuse Research Foundation: Alexandria, VA, USA, 2015.

26. Jjemba, P.K. Environmental Microbiology: Principles and Applications; Science Publisher, Inc.: Enfield, UK, 2004.

27. Zhang, C. A Study on Urban Water Reuse Management Modeling. Master's Thesis, University of Waterloo, Waterloo, ON, Canada, 2004. Available onine: http://www.collectionscanada.gc.ca/ obj/s4/f2/dsk3/ OWTU/TC-OWTU-481.pdf (accessed on 25 March 2015).

28. Jjemba, P.K.; Weinrich, L.A.; Cheng, W.; Giraldo, E.; LeChevallier, M.W. Re-growth of opportunistic pathogens and algae in reclaimed water distribution systems. Appl. Environ. Microbiol. 2010, 76, 4169-4178.

29. Piao, Z.; Sze, C.C.; Barysheva, O.; Iida, K.; Yoshida, S. Temperature-regulated formation of mycelial mat-like biofilms by Legionella pneumophila. Appl. Environ. Microbiol. 2006, 72, 16131622.

30. Declerck, P.; Behets, J.; Margineanu, A.; van Hoef, V.; DeKeersmaecker, B.; Ollevier, F. Replication of Legionella pneumophila in biofilms of water distribution pipes. Microbiol. Res. 2009, 164, 593-603.

31. Abu Kwaik, Y. Invasion of mammalian and protozoan cells by Legionella pneumophila. In Bacterial Invasion into Eukaryotic Cells; Schlaeger, J.J., Hacker, J., Eds.; Kluwer Academic/Plenum Publishers: New York, NY, USA, 2000; Volume 33, pp. 383-407. 
32. Kim, B.R.; Anderson, J.E.; Mueller, S.A.; Gaines, W.A.; Kendall, A.M. Literature reviewEfficacy of various disinfectants against Legionella in water systems. Water Res. 2002, 36, 44334444.

33. Abdel-Nour, M.; Duncan, C.; Low, D.E.; Guyard, C. Biofilms: The stronghold of Legionella pneumophila. Int. J. Mol. Sci. 2013, 14, 21660-21675.

34. Berk, S.G.; Ting, R.S.; Turner, G.W.; Ashburn, R.J. Production of respirable vescicles containing live Legionella pneumophila cells by two Acanthamoeba spp. Appl. Environ. Microbiol. 1998, 64, 279-286.

35. Lau, H.Y.; Ashbolt, N. The role of biofilms and protozoa in Legionella pathogenesis: Implications for drinking water. J. Appl. Microbiol. 2009, 107, 368-378.

36. Paszko-Kolva, C.; Shahamat, M.; Colwell, R.R. Longterm survival of Legionella pneumophila serogroup lunder low-nutrient conditions and associated morphological changes. FEMS Microbiol. Ecol. 1992, 102, 45-55.

37. Molmeret, M.; Bitar, D.M.; Han, L.; Kwaik, Y.A. Cell biology of the intracellular infection by Legionella pneumophila. Microbes Infect. 2004, 6, 129-139.

38. Dupuy, M.; Mazoua, S.; Berne, F.; Bodet, C.; Garrec, N.; Herbelin, P.; Ménard-Szczebara, F.; Oberti, S.; Rodier, M.-H.; Soreau, S.; et al. Efficiency of water disinfectants against Legionella pneumophila and Acanthamoeba. Water Res. 2011, 45, 1087-1094.

39. Thomas, V.; Loret, J.F.; Jousset, M.; Greub, G. Biodiversity of amoebae and amoebae-resisting bacteria in a drinking water treatment plant. Environ. Microbiol. 2008, 10, 2728-2745.

40. Berk, S.G.; Gunderson, J.H.; Newsome, A.L.; Farone, A.L.; Hayes, B.J.; Redding, K.S.; Uddin, N.; Williams, E.L.; Johnson, R.A.; Farsian, M.; et al. Occurrence of infected amoebae in cooling towers compared with natural aquatic environments: Implications for emerging pathogens. Environ. Sci. Technol. 2006, 40, 7440-7444.

41. Gião, M.S.; Wilks, S.A.; Azevedo, N.F.; Vieira, M.J.; Keevil, C.W. Comparison between standard culture and peptide nucleic acid 16S rRNA hybridization quantification to study the influence of physico-chemical parameters on Legionella pneumophila survival in drinking water biofilms. Biofouling 2009, 25, 343-351.

42. Miller, J.; Simpson, G.D. Chemical control of Legionella. Available online: http://www.ibrarian.net/navon/paper/Chemical_Control_of_Legionella.pdf?paperid=9579048 (accessed on 18 March 2015).

43. Mouchtouri, V.A.; Goutziana, G.; Kremastinou, J.; Hadjichristodoulou, C. Legionella species colonization in cooling towers: Risk factors and assessment of control measures. Am. J. Infect. Control 2010, 38, 50-55.

44. Kilvington, S.; Gray, T.; Dart, J.; Morlet, N.; Beeching, J.R.; Frazer, D.G.; Matheson, M. Acanthamoeba keratitis: The role of domestic tap water contamination in the United Kingdom. Invest. Ophtalmol. Vis. Sci. 2004, 45, 165-169.

45. Thomas, V.; Herrera-Rimann, K.; Blanc, D.S.; Greub, G. Biodiversity of amoebae and amoebae-resisting bacteria in a hospital water network. Appl. Environ. Microbiol. 2006, 72, 2428-2438.

46. Elliot, J.A.; Johnson, W. Virulence conversion of Legionella pneumophila serogroup 1 by passage in guinea pigs and embryonated eggs. Infect. Immun. 1982, 35, 943-946. 
47. US EPA (United States Environmental Protection Agency). Method Validation of U.S. Environmental Protection Agency Microbiological Methods of Analysis. Available online:

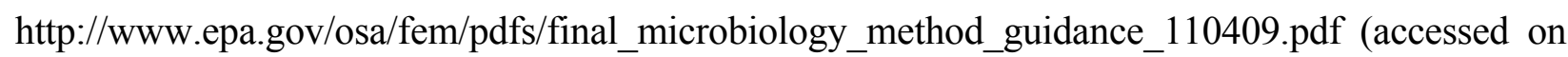
20 April 2010).

48. Magliano, A.C.M.; da Silva, F.M.; Teixeira, M.M.G.; Alfieri, S.C. Genotyping, physiological features and proteolytic activities of a potentially pathogenic Acanthamoeba sp. isolated from tap water in Brazil. Exp. Parasitol. 2009, 123, 231-235.

49. De Jonckheere, J.F. Occurrence of Naegleria and Acanthamoeba in aquaria. Appl. Environ. Microbiol. 1979, 38, 590-593.

50. Lorenzo-Morales, J.; Lindo, J.F.; Martínez, E.; Calder, D.; Figueruelo, E.; Valladares, B.; Ortega-Rivas, A. Pathogenic Acanthamoeba strains from water sources in Jamaica, West Indies. Ann. Trop. Med. Parasitol. 2005, 99, 751-758.

51. Lorenzo-Morales, J.; Ortega-Rivas, A.; Foronda, P.; Martínez, E.; Valladares, B. Isolation and identification of pathogenic Acanthamoeba strains in Tenerife, Canary Islands, Spain from water sources. Parasitol. Res. 2005, 95, 273-277.

52. Rivera, F.; Ramíres, E.; Bonilla, P.; Calderón, A.; Gallagos, E.; Rodríguez, S.; Ortiz, R.; Zaldívar, B.; Ramírez, P.; Durán, A. Pathogenic and free-living amoebae isolated from swimming pools and physiotherapy tubs in Mexico. Environ. Res. 1993, 62, 43-52.

53. Caumo, K.; Frasson, A.P.; Pens, C.J.; Panatieri, L.F.; Frazzon, A.P.G.; Rott, M.B. Potentially pathogenic Acanthamoeba in swimming pools: A survey in the southern Brazilian city of Porto Alegre. Ann. Trop. Med. Parasit. 2009, 103, 477-485.

54. Edagawa, A.; Kimura, A.; Kawabuchi-Kurata, T.; Kusuhara, Y.; Karanis, P. Isolation and genotyping of potentially pathogenic Acanthamoeba and Naegleria species from tap-water sources in Osaka, Japan. Parasitol. Res. 2009, 105, 1109-1117.

55. Bartrand, T.A.; Causey, J.J.; Clancy, J. Naegleria fowleri: An emerging drinking water pathogen. J. Am. Water Works Assoc. 2014, doi:10.5942/jawwa.2014.106.0140.

56. Réveiller, F.L.; Varenne, M.-P.; Pougnard, C.; Cabanes, P.-A.; Pringuez, E.; Pourima, B.; Legastelois, S.; Pernin, P. An enzyme-linked immunosorbent assay (ELISA) for the identification of Naegleria fowleri in environmental water samples. J. Eukaryot. Microbiol. 2003, 50, 109-113.

57. Pernin, P.; Grelaud, G. Application of isoenzymatic typing to the identification of nonaxenic strains of Naegleria (Protozoa, Rhizopoda). Parasitol. Res. 1989, 75, 595-598.

58. Pernin, P.; de Jonckheere, J.F. Appearance in Europe of Naegleria fowleri displaying the Australian type of restriction-fragment-length polymorphism. Parasitol. Res. 1992, 78, 479-481.

59. Pernin, P.; Pélandakis, M.; Rouby, Y.; Faure, A.; Siclet, F. Comparative recoveries of Naegleria fowleri amoebae from seeded river water by filtration and centrifugation. Appl. Environ. Microbiol. 1998, 64, 955-959.

60. John, D.T.; Howard, M.J. Seasonal distribution of pathogenic free-living amebae in Oklahoma waters. Parasitol. Res. 1995, 81, 193-201.

61. Behets, J.; Declerck, P.; Delaedt, Y.; Verelst, L.; Ollevier, F. A duplex real-time PCR assay for the quantitative detection of Naegleria fowleri in water samples. Water Res. 2007, 41, 118-126.

62. Réveiller, F.L.; Cabanes, P.-A.; Marciano-Cabral, F.M. Development of a nested PCR assay to detect the pathogenic free-living amoeba Naegleria fowleri. Parasitol. Res. 2002, 88, 443-450. 
63. Pélandakis, M.; Pernin, P. Use of multiplex PCR and PCR restriction enzyme analysis for detection and exploration of the variability in the free-living amoeba Naegleria in the environment. Appl. Environ. Microbiol. 2002, 68, 2061-1065.

64. Marciano-Carbral, F.; MacLean, R.; Mensah, A.; LaPat-Polasko, L. Identification of Naegleria fowleri in domestic water sources by nested PCR. Appl. Environ. Microbiol. 2003, 69, 5864-5869.

65. Blair, B.L.; Sarkar, P.; Bright, K.R.; Marciano-Cabral, F.; Gerba, C.P. Naegleria fowleri in well water. Emerg. Infect. Dis. 2008, 14, 1499-1501.

66. Ng, D.L.K.; Koh, B.B.; Tay, L.; Heng, B.H. Comparison of polymerase chain reaction and conventional culture for the detection of legionellae in cooling tower waters in Singapore. Lett. Appl. Microbiol. 1997, 24, 214-216.

67. Palmer, C.J.; Bonilla, G.F.; Roll, B.; Paszko-Kolva, C.; Sangermano, L.R.; Fujioka, R.S. Detection of Legionella species in reclaimed water and air with the EnviroAmp Legionella PCR kit and direct fluorescent antibody staining. Appl. Environ. Microbiol. 1995, 61, 407-412.

68. Palmer, C.J.; Tsai, Y.L.; Paszko-Kolva, C.; Meyer, C.; Sangermano, L.R. Detection of Legionella species in sewage and ocean water by polymerase chain reaction, direct fluorescent antibody, and plate culture methods. Appl. Environ. Microbiol. 1993, 59, 3618-3624.

69. Miyamoto, H.; Yamamoto, H.; Arima, K.; Fujii, J.; Maruta, K.; Izu, K.; Shiomori, T.; Yoshida, S.-C. Development of a new seminested PCR method for detection of Legionella species and its application to surveillance of Legionellae in hospital cooling tower water. Appl. Environ. Microbiol. 1997, 63, 2489-2494.

70. Mario, F.; Corvec, S.; Caroff, N.; Le Gallou, F.; Drugeon, H.; Reynaud, A. Real-time PCR assay for the detection and quantification of Legionella pneumophila in environmental water samples: Utility for daily practice. Internation. J. Hyg. Environ. Health 2008, 211, 403-411.

71. Merault, N.; Rusniok, C.; Jarraud, S.; Gomez-Valero, L.; Cazalet, C.; Marin, M.; Brachet, E.; Aegerter, P.; Gaillard, J.L.; Etienne, J. Specific real-time PCR for simultaneous detection and identification of Legionella pneumophila serogroup 1 in water and clinical samples. Appl. Environ. Microbiol. 2011, 77, 1708-1717.

72. Nocker, A.; Cheung, C.Y.; Camper, A.K. Comparison of propidium monoazide with ethidium monoazide for differentiation of live $v s$. dead bacteria by selective removal of DNA from dead cells. J. Microbiol. Methods 2006, 67, 310-320.

73. Pan, Y.; Breidt, F., Jr. Enumeration of Viable Listeria monocytogenes Cells by Real-Time PCR with propidium monoazide and ethidium monoazide in the presence of dead cells. Appl. Environ. Microbiol. 2007, 73, 8028-8031.

74. Brescia, C.C.; Griffin, S.M.; Ware, M.W.; Varughese, E.A.; Egorov, A.I.; Villegas, E.N. Cryptosporidium propidium monoazide-PCR, a molecular biology-based technique for genotyping of viable Cryptosporidium Oocysts. Appl. Environ. Microbiol. 2009, 75, 6856-6863.

75. Gedalanga, P.B.; Olson, B.H. Development of a quantitative PCR method to differentiate between viable and nonviable bacteria in environmental water samples. Appl. Microbiol. Biotechnol. 2009, 82, 587-596.

76. Varma, M.; Field, R.; Stinson, M.; Rukovets, B.; Wymer, L.; Haugland, R. Quantitative real-time PCR analysis of total and propidium monoazide-resistant fecal indicator bacteria in wastewater. Water Res. 2009, 43, 4790-4801. 
77. Rajal, V.B.; McSwain, B.S.; Thompson, D.E.; Leutenegger, C.M.; Kildare, B.J.; Wuertz, S. Validation of hollow fiber ultrafiltration and real-time PCR using bacteriophage PP7 as surrogate for the quantification of viruses from water samples. Water Res. 2007, 41, 1411-1422.

78. Cargill. K.L.; Pyle, B.H.; Sauer, R.L.; McFeters, G.A. Effects of culture conditions and biofilm formation on the iodine susceptibility of Legionella pneumophila. Can. J. Microbiol. 1992, 38, 423-429.

79. King, C.H.; Shotts, E.B.; Wooley, R.E.; Porter, K.G. Survival of coliforms and bacterial pathogens with protozoa during chlorination. Appl. Environ. Microbiol. 1988, 54, 3023-3033.

80. Storey, M.V.; W.-K.J.; Ashbolt, N.J.; Stenström, T.A. The efficacy of heat and chlorine treatment against thermotolerant Acanthamoebae and Legionellae. Scand. J. Infect. Dis. 2004, 36, 656-662.

81. Miyamoto, M.; Yamaguchi, Y; Sastsu, M. Disinfectant effects of hot water, ultraviolet light, silver ions and chlorine on stains of Legionella and nontuberculous mycobacteria. Micrbios 2000, 101, 7-13.

82. Kilvington, S.; Price, J. Survival of Legionella pneumophila within cysts of Acanthamoeba polyphaga following chlorine exposure. J. Appl. Bacteriol. 1990, 68, 519-525.

83. Muraca, P.; Stout, J.E.; Yu, V.L. Comparative assessment of chlorine, heat, ozone, and UV light for killing Legionella pneumophila within a model plumbing system. Appl. Environ. Microbiol. 1987, 53, 447-453.

84. De Jonckheere, J.; van de Voorde, H. Differences in destruction of cysts of pathogenic and nonpathogenic Naegleria and Acanthamoeba by chlorine. Appl. Environ. Microbiol. 1976, 31, 294-297.

85. Connell, G.F. The Chlorination/Chloramination Handbook; American Water Works Association: Denver, CO, USA, 1996.

86. Domingue, E.L.; Tyndall, R.L.; Mayberry, W.R.; Pancorbo, O.C. Effects of three oxidizing biocides on Legionella pneumopila serogroup 1. Appl. Environ. Microbiol. 1988, 54, 741-747.

87. Loret, J.F.; Jousset, M.; Robert, S.; Saucedo, G.; Ribas, F.; Thomas, V.; Greub, G. Amoebae-resisting bacteria in drinking water: Risk assessment and management. Water Sci. Technol. 2008, 58, 571-577.

88. Jjemba, P.K.; Johnson, W.; Bukhari, Z.; LeChevallier, M.W. Review of the leading challenges in maintaining reclaimed water quality during storage and distribution. J. Water Reuse Desalin. 2014, 4, 209-237.

89. Walker, J.T.; Mackerness, C.W.; Mallon, D.; Makin, T.; Williets, T.; Keevil, C.W. Control of Legionella pneumophila in a hospital water system by chlorine dioxide. J. Ind. Microbiol. 1995, 15, 384-390.

90. Kuchta, J.M.; Navratil, J.S.; Shepherd, M.E.; Wadowsky, R.M.; Dowling, J.N.; States, S.J.; Yee, R.B. Impact of chlorine and heat on the survival of Hartmannella vermiformis and subsequent growth of Legionella pneumophila. Appl. Environ. Microbiol. 1993, 59, 4096-4100.

91. Campos, C.; Loret, J.F.; Cooper, A.J.; Kelly, R.F. Disinfection of domestic water systems for Legionella pneumophila. J. Water SRT 2003, 52, 341-354.

92. Flannery, B.; Gelling, L.B.; Vugia, D.J.; Weintraub, J.M.; Salerno, J.J.; Conroy, M.J.; Stevens, V.A.; Rose, C.E.; Moore, M.R.; Fields, B.S.; et al. Reducing Legionella colonization of water systems with monochloramine. Emerg. Infect. Dis. 2006, 12, 588-596. 
93. Duda, S.; Kandiah, S.; Stout, J.E.; Baron, J.L.; Yassin, M.; Fabrizio, M.; Ferrelli, J.; Hariri, R.; Wagener, M.W.; Goepfert, J.; et al. Evaluation of a new monochloramine generation system for controlling Legionella in building hot water systems. Infect. Control 2014, 35, 1356-1363.

94. Perrine, D.; Barbier, D.; Georges, P.; Langlais, B. The destruction by ozone of ameba cysts in recycled swimming pool water. Effluent Water Treat. J. 1984, 24, 299.

95. Gulyas, H.; Hemmerling, L.; Sekoulov, I. Potential advanced treatment of oil reclaimed wastewaters for removal of organic solutes. J. Water Wastewater Res. 1991, 24, 253-257.

96. Sekoulov, I.; Figueroa, A.; Oles, J. Investigation on wastewater reuse on passenger aircraft. Water Sci. Technol. 1991, 23, 10-12.

97. Langlais, B.; Recknow, D.; Brink, D.R. Ozone in Water Treatment: Applications and Engineering; Lewis Publishers: Chelsea, MI, USA, 1991.

98. Botzenhart, K.; Tarcson, G.M.; Ostruschka, M. Inactivation of bacteria and coliphages by ozone and chlorine dioxide in a continuous flow reactor. Water Sci. Technol. 1993, 27, 363-370.

99. Wickramanayake, G.B.; Rubin, A.J.; Sproul, O.J. Inactivation of Naegleria and Giardia cysts in water by ozonation. J. Water Pollut. Control Fed. 1984, 56, 983-988.

100. Langlais, B.; Perrine, D. Action of ozone on trophozoites and free amoeba cysts, whether pathogenic or not. Ozone Sci. Eng. 1986, 8, 187-198.

101. Loret, J.F.; Jousset, M.; Robert, S.; Anselme, C.; Saucedo, G.; Ribas, F.; Martinez, L.; Catalan, V. Elimination of free-living amoebae by drinking water treatment processes. Eur. J. Water Qual. 2008, 39, 37-50.

102. Schwartz, T.; Hoffmann, S.; Obst, U. Formation of natural biofilms during chlorine dioxide and u.v. disinfection in a public drinking water distribution system. J. Appl. Microbiol. 2003, 95, 591-601.

103. Clarke, S.H. Ultraviolet Light Disinfection in the Use of Individual Water Purification Devices. Available online: http://phc.amedd.army.mil/PHC\%20Resource\%20Library/Ultraviolet $\% 20$ Light $\%$ 20Disinfection\%20in\%20the \%20Use\%20of\%20Individual\%20Water\%20Purification \%20Devices. pdf (accessed on 19 March 2015).

104. Cervero-Aragó, S.; Sommer, R.; Araujo, R.M. Effect of irradiation (253.7 nm) on free Legionella and Legionella associated with its amoebae hosts. Water Res. 2014, 67, 299-309.

105. Brooks, D.; van Stone, G.; Lem, W. UV Experience for Inactivating Cyrptosporidium in Surface Water Plants. Available online: http://www.environmental-expert.com/Files\%5C11087\%5 Carticles\%5C5662\%5Cuv_01_33.pdf(accessed on 19 March 2015).

106. Hijnen, W.A.M.; Beerendonk, E.F.; Medema, G.J. Inactivation credit of UV radiation for viruses, bacteria and protozoan (oo)cysts in water: A review. Water Res. 2006, 40, 3-22.

107. Lin, Y.-S.; Vidic, R.D.; Stout, J.E.; Yu, V.L. Individual and combined effects of copper and silver ions on inactivation of Legionella pneumophila. Appl. Environ. Microbiol. 1996, 30, 1905-1913.

108. Rossoni, E.M.M.; Gaylarde, C.C. Comparison of sodium hypochlorite and peracetic acid as sanitizing agents for stainless steel food processing surfaces using epifluorescence microscopy. Int. J. Food Microbiol. 2000, 61, 81-85.

109. Baldry, M.G.C.; French, M.S.; Slater, D. The activity of peracetic acid on sewage indicator bacteria and viruses. Water Sci. Technol. 1991, 24, 353-357. 
110. Wutzler, P.; Sauerbrei, A. Virucidal efficacy of a combination of $0.2 \%$ peracetic acid and $80 \%$ (v/v) ethanol (PAA-ethanol) as a potential hand disinfectant. J. Hosp. Infect. 2000, 46, 304-308.

111. Kilvington, S. Activity of water biocide chemicals and contact lens disinfectants on pathogenic free-living amoebae. Int. Biodeterior. 1990, 26, 127-138.

112. Barker, J.; Lambert, P.A.; Brown, M.R. Influence of intra-amoebic and other growth conditions on the surface properties of Legionella pneumophila. Infect. Immun. 1993, 61, 3505-3510.

113. Goldoni, P.; Sinibaldi, L.; Valenti, P.; Orsi, N. Metal complexes of lactoferrin and their effect on the intracellular multiplication of Legionella pneumophila. Biometals 2000, 13, 15-22.

114. Hindré, T.; Brüggemann, H.; Buchrieser, C.; Héchard, Y. Transcriptional profiling of Legionella pneumophila biofilm cells and the influence of iron on biofilm formation. Microbiology 2008, 154, 30-41.

115. Raftery, T.; Lindler, H.; McNealy, T.L. Altered host-pathogen interactions due to nanoparticle interaction with a bacterial biofilm. Microb. Ecol. 2013, 65, 496-503.

(C) 2015 by the authors; licensee MDPI, Basel, Switzerland. This article is an open access article distributed under the terms and conditions of the Creative Commons Attribution license (http://creativecommons.org/licenses/by/4.0/). 